Article

\title{
Green Governance and International Business Strategies of Emerging Economies' Multinational Enterprises: A Multiple-Case Study of Chinese Firms in Pollution-Intensive Industries
}

\author{
Runhui Lin ${ }^{1,2, *}$, Yuan Gui ${ }^{1}$, Zaiyang Xie ${ }^{1}$ and Lu Liu ${ }^{3}$ \\ 1 Business School, Nankai University, Tianjin 300071, China; gynankai@126.com (Y.G.); \\ cherie620@126.com (Z.X.) \\ 2 China Academy of Corporate Governance, Nankai University, Tianjin 300071, China \\ 3 School of Economics and Management, Shandong University of Science and Technology, \\ Qingdao 266590, China; LiuLu_77@126.com \\ * Correspondence: linrh@nankai.edu.cn; Tel.: +86-18222251696
}

Received: 30 December 2018; Accepted: 12 February 2019; Published: 15 February 2019

\begin{abstract}
With the global consensus on the need for sustainability practices, green governance has attracted increasing attention from international business (IB) scholars and multinational enterprise (MNE) managers. In this study, we propose a more fine-grained framework of the green governance context along two dimensions: foreign direct investment (FDI) policy and environmental regulation. Then, we examine the framework using cluster analysis. On the basis of a multiple-case study comprising 11 Chinese MNEs in pollution-intensive industries operating in four different green governance contexts, we conclude that (1) the green governance context is a significant factor in MNEs' global location choices and is an important driving force behind MNEs' response patterns; (2) environmental capabilities enable MNEs to surmount a host country's environmental entry barrier and facilitate wider global business deployment; (3) technological capabilities increase MNEs' competitive edge and allow them to better harness a host country's growth opportunities; (4) there are four types of green governance response patterns, and the details of the proposed classification structure and its validation are presented; and (5) both strict environmental regulation and friendly FDI policy can positively influence MNEs' adoption of more active response patterns, and greater availability of environmental and technological capabilities does not affect MNEs' environmental commitment. This study contributes to the international strategy-capability-environment alignment of emerging economies' multinational enterprises (EMNEs) in different green governance contexts.
\end{abstract}

Keywords: green governance; EMNEs; location choice; response pattern; environmental capabilities; technological capabilities; strategic fit

\section{Introduction}

The costly effects of environmental degradation continue to accumulate and affect economies worldwide. With the widespread concern for environmental protection and sustainable development, there is a global trend of transitioning to green economies. Recent research discussing this trend has used the term "green governance" and introduced sustainability and environmental protection concepts to economic development [1]. Green governance emphasizes the balance between economic growth and environmental protection [1-3]. Governments around the world have increasingly recognized foreign direct investment (FDI) as an important driver of economic growth [4,5]. FDI can generate financial resources and foreign technology, and it is usually associated with new job 
opportunities and enhanced productivity. Many countries are limited in infrastructure and factor market development, and they rely heavily on pollution-intensive industries, such as the extractive sectors, to support their nation's broad economic and development agendas [6]. At the same time, pollution-intensive industries are characterized by high levels of environmental contamination and toxic release [7], and lax regulatory standards worsen the situation. This combination often leads to further deterioration of environmental quality and sparks mounting public concerns and governmental efforts that are focused on environmental issues. Therefore, governments need to achieve a balance between attracting foreign investment and protecting the local environment.

Previous research on host countries' governmental policies and regulations has emphasized their critical influence on firms' international business (IB) strategies and practices [8,9]. The effects of FDI policies and environmental regulations on multinationals have become two major focus areas for IB scholars and multinational enterprise (MNE) managers [10]. The two factors are especially likely to influence firms' IB strategies [11,12]. Moreover, these institutional incentives and limitations constitute the basis of governmental green governance policies [1]. However, the existing roughly categorized green governance contexts often confuse scholars and managers. This confusion is compounded by the economic and juridical heterogeneity of countries. Green governance has progressed at different paces in different countries all over the world. Some countries (such as Mongolia and Venezuela) are impoverished in FDI attraction and environmental protection [13,14]. Other countries (such as Thailand and Nigeria) value foreign investment far more than environmental quality $[15,16]$ : in these countries, the green value is subordinate to economic priority. In contrast, some countries (such as Saudi Arabia and Kenya) tend to value and prioritize environmental quality $[13,15,17]$. Other countries (such as the United Kingdom and Canada) strike the right balance between attracting foreign investment and protecting the environment, and these countries achieve a superior economic and ecologic performance $[13,15,16]$. We previously noted that the vastly different "rules of the game" [18] considerably shape the strategies and behaviors of emerging economies' MNEs (EMNEs) [19,20]. Although the existing literature has differentiated the internationalization opportunities and challenges into developed and developing contexts with differently developed institutional arrangements, a more fine-grained delineation of green governance contexts may be warranted.

The green governance context is complex and commonly state-linked [1,21]. These governance contexts constitute and define an established order within which businesses operate. Contingency theory emphasizes that firms' strategies need to be aligned with internal capabilities and external contexts [22]. Recent studies from advanced economies' MNEs (AMNEs) have recognized that both contextual and firm-specific factors help explain international diversification. However, less attention has been given to the internal and external factors of EMNEs' IB strategies in different green governance contexts. Despite their increasing importance as globalization advances, there remain significant gaps in our understanding of the "fit" between their strategies and capabilities in the external green governance context. Filling this gap is important, partly because of the substantial increase in global expansion by MNEs from China, India, and Brazil, but principally because the lessons and their supporting evidence for multinationals from advanced economies may not be directly applicable to EMNEs [23]. EMNEs often face deficits in both capability and legitimacy [24,25]. Their investment and operations in foreign countries more easily draw greater public concern about and governmental scrutiny of their environmental impacts [26,27]. Thus, EMNEs, especially those penetrating advanced economies, face significant challenges in their attempt to adapt to the green governance context. However, firms have specific capabilities that can be developed and deployed to enable their proactive preparation to harness opportunities and mitigate threats [28]. Consequently, this study aims to investigate how different green governance contexts and firms' specific capabilities influence EMNEs' IB strategies. Explicitly, this study investigates the following four questions:

1. Can we extend our understanding to a more fine-grained typology of the green governance context?

2. Why do EMNEs choose different green governance locations (countries)? 
3. What are the kinds of response patterns of EMNEs in different host green governance contexts?

4. Why do green governance response patterns differ from each other?

To address the above questions, this research was conducted over three progressive and interrelated studies. The starting point was a comprehensive revisiting of the green governance context typology. We identified four comprehensive, mutually exclusive types of green governance contexts along two dimensions, which reflect the different degrees of growth priorities and green priorities among countries. Then, we selected 11 Chinese MNEs operating in 11 countries belonging to these four green governance contexts to investigate the antecedents of sample firms' location choices and their green governance response patterns. Finally, through case analysis, we examined how external green governance contexts and firm-specific capabilities influence MNEs' location choices and their green governance response patterns. By codifying and clustering sample firms' practices, we identified four clusters in the sampled countries, with each cluster focusing on a kind of response pattern to a corresponding green governance context. We suggest that, in order to be successful, EMNEs should choose the appropriate investment locations and response patterns in different green governance contexts that best "fit" their specific capabilities. In this way, this study contributes to the current body of literature with the claim that the heterogeneous internationalization motives and practices of EMNEs can be explained by looking at the firms' antecedents that capture their host contexts' peculiarities and firms' specific capabilities.

The paper is structured as follows: Section 2 reviews the related literature that explores the connotation of green governance and classification of green governance contexts, summarizes the effects of FDI policy and environmental regulation on EMNEs' IB strategies, and analyzes EMNEs' IB strategies through a resource-based view (RBV); Section 3 describes the materials and methods; Section 4 depicts the findings and results and offers two propositions; Section 5 discusses the findings and presents a theorized conceptual framework; and finally, Section 6 concludes the study by summarizing the main findings and contributions of the paper and shedding light on future research.

\section{Literature Review}

\subsection{Green Governance and Green Governance Context Classification}

In recent decades, studies on green governance have emerged, and it has become a topic discussed internationally because environmental problems are now a global concern [1]. The connotation of green governance is widely interpreted from different aspects. Some scholars have analyzed it from the "green" color perspective and defined it as the use of governance mechanisms to influence organizations' green practices $[29,30]$. Some scholars have researched the mechanism and implementation of green governance, and they have pointed out that open innovation activities can effectively deal with the externalities of resources and facilitate sustainable development [1,31-33]. Some scholars have indicated the importance of green institutional contexts [34,35]. However, a widely accepted definition of green governance is still lacking. Broadly defined, governance refers to the mechanisms by which power is exercised in the management of a country's economic and social resources for development [36]. This representation indicates that governance involves the exercise of authority or power. Therefore, the roles, interrelations, and interactions among politics, economics, administrations, and laws in a focal country are of the utmost importance in understanding governance [3].

The world's development process is at a crossroad. The high-growth, resource-intensive, and pollution-intensive development model that many countries are pursuing and used to pursue has caused severe environmental pollution and deterioration, and the unsustainable growth model has already reached its limits [31,37]. Global environmental crises have prompted a rethinking of the old "economic growth-first" development model among countries. An environmentally sustainable path of economic growth in favor of alternative models, such as green growth-which is defined as a model to achieve efficient, clean, and flexible production processes without slowing down economic 
growth [38]—is becoming more and more appealing [39]. However, the environmentally conscious economic growth path is not a natural outcome, and governance is seen as a means to steer the process of sustainable development [3]. With respect to green governance, the government is the policy provider by using its dominant position and political authority to develop and implement policies that establish mandatory approaches to sustainable development [1].

A key substantive challenge for each country is how to reconcile economic growth with environmental quality. Environmental regulations can raise compliance costs for firms, but provide environmental quality (a public good) to citizens. From a cost-saving perspective, firms have incentives to relocate their operations to countries with lax environmental standards, and strict environmental regulations may deter foreign investors [10]. However, FDI is an important source of capital that complements domestic private investment, is usually associated with new job opportunities and enhancement of technology transfer, and boosts overall economic growth in host countries [40]. Therefore, countries could face the dilemma of either letting environmental quality deteriorate or running the risk of deterring foreign investors [10].

Some countries prioritize economic growth over environmental issues and continue the unsustainable, inequitable development pathway that dominated economic thinking in western countries several decades ago. However, evidence has proved that the argument "grow dirty and clean up later" is misleading [38]. Some countries prioritize environmental quality over economic growth, because many of these countries have experienced the bitterness of environmental deterioration. Environmental crises, such as air pollution, water contamination, and land degradation, pose immediate threats to countries' growth and development. Some countries perform poorly in both aspects. Some countries place great emphasis on both and create a virtuous cycle of green growth. We note the rising European countries' leadership in green governance since the late 1980s [41,42]. They have been setting good examples while implementing green governance approaches. For example, the European agreements on acid rain include a monitoring process that is able to evaluate the accuracy of emissions data reported by states and increase the reliability of reported information [43]. Through continuous legislative efforts, Great Britain has been gradually implementing green governance, and ethical businesses have formed [44].

Previous research efforts have roughly classified green governance contexts worldwide into developed and developing countries, e.g., [10], rich and poor countries e.g., [45], and north and south countries e.g., [46]. Actually, the difference between a country's green governance situation is more complex than a simple dichotomy. For instance, in recent decades, many developing countries have experienced significant progress in strengthening their environmental regulations [47]. The perception that the governments of developing countries "grudgingly address environmental degradation" may no longer be accurate today [48]. Indeed, there are a growing number of developing countries that have integrated environmental protection into their economic and developmental interests [49]. A rationally developed typology can capture the major features among the dimensions analyzed, thus facilitating knowledge exploration, communication, and memorization [50]. In this study, we explore and adopt a fine-grained typology of the green governance context to extend the theoretical research on green governance issues and provide useful guidance for scholars, managers, and policymakers. We propose a new typology of the green governance context along two dimensions-FDI policy and environmental regulation - to provide a two-by-two matrix that contains more possible governmental green governance scenarios.

\subsection{FDI Policy and EMNEs' IB Strategies}

Governments represent major sources of uncertainty, mainly because they have the power and authority to shape firms' competitive environments [51,52]. Often, MNE managers value economic growth in a country because it enhances the likelihood that MNEs will earn acceptable returns on invested capital [53]. Governments can enact policies that facilitate economic growth and promote a positive environment for foreign investments, such as tax holidays, investment subsidies, and labor 
market flexibility [53-55]. However, many governments value local votes and support more than foreign investment. To this end, host governments may intervene in foreign firms' operations and largely favor local firms' interests over foreign firms' interests [56]. These policies create an environment that discourages foreign investments and expansion. For example, government interventions, such as salary and price controls, limit MNEs' flexibility and increase their exposure to unfavorable market conditions. Likewise, many governments restrict the ownership and shareholder rights of foreign investors, thereby placing a foreign equity cap on and limiting or prohibiting foreign investment in key economic sectors [57].

For firms, governmental FDI policies influence their operating costs and financial performance. For example, in a favorable investment climate, governments provide and promote public goods and create laws to protect private property to guarantee the country's economic growth [53]. MNEs can receive fair or even preferential treatment $[56,58]$, which quells investors' concerns and increases firms' profit expectations. Consequently, firms are more likely to expand their businesses to these countries to exploit policy and market opportunities $[59,60]$. On the contrary, when local policies toward FDI are overly strong and unfriendly, firms operating there will suffer great difficulty, which increases their cost burden and requires strategic changes in firms [61-64]. Reducing firms' profitability creates a hostile investment climate, which is likely to reduce firms' incentives to engage in FDI and drive firms to use avoidance/delay strategies, including divesting or postponing entry into a country [65]. Even if a focal firm chooses to invest in an unfriendly country, they try to avoid large resource commitments in this situation [66].

An important drawback of previous research is that it has not accounted for firm-specific heterogeneity, such as their specialized capabilities. Furthermore, in the green governance scenario, most of the existing research has not considered the effects of both FDI policy and environmental regulations simultaneously.

\subsection{Environmental Regulation and EMNEs' IB Strategies}

Environmental regulation generally exerts a strong influence on a firm's location choice and environmental approach, because the regulatory elements can have a profound impact on growth and profitability [67-70]. It is frequently argued that firms tend to invest in different countries and adopt diverse sets of environmental practices since they perceive regulatory pressures differently due to some external and firm-specific contingency factors [10,71,72].

For a firm's location choice, there are two competing perspectives. The "pollution haven hypothesis" (PHH) argues that firms intend to locate their productions in countries with lax environmental regulations $[70,73,74]$. The main assumption of the $\mathrm{PHH}$ is that compliance with strict environmental regulations imposes costs on firms and affects the location decisions of MNEs [69]. In terms of environmental regulatory requirements, MNEs will prefer locations which are cheaper and allow for a more efficient maximization of profits [75]. On the contrary, the "Porter hypothesis" argues that costs for compliance with stringent environmental regulations will be offset by cost reduction, technology development, and consumers' green demand stimulated by the regulations [76,77]. So, strict environmental regulations may be beneficial to MNEs. Although scholars and policymakers have been engaged in heated debate about the linkage between environmental regulations and firms' location choices, empirical evidence on the topic is decidedly mixed $[10,78]$. The lack of consideration of governmental FDI policy may contribute to the ambiguity.

Host environmental regulations can take many forms to shape firms' local response practices. They can dictate technologies that must be used, stipulate specific environmental outcomes that must be achieved, create economic frameworks for redistributing environmental costs and benefits, and so on [11]. Under different regulatory contexts, environmental management models show a wide variety of characteristics. In general, firms' patterns on environmental practices may lie along a continuum from "reactive" to "proactive" [79]. A reactive response refers to firms' responses that are not committed to protecting the natural environment or are limited to reacting to mandatory legislative 
requirements [80]. This approach is based on practices and techniques of end-of-pipe solutions that attempt to solve pollution that already exists [81]. On the contrary, a proactive strategy is related to systematic methods, also known as environmental stewardship, that will lead firms to integrate the voice of the environment into product design and manufacturing processes [82] that are aimed at preventing the occurrence of problems by dealing with their sources [83]. Many studies have concentrated on the relationship between an organization's environmental commitment and financial performance [84]. Most of these studies only consider stakeholder pressure and lack any examination of economic incentives, causing ambiguous results.

Although the currently available research has tried to categorize firms' local response patterns, it has focused predominantly on explaining motivations and practices within firms from AMNEs e.g., [85-89]. Compared with AMNEs, EMNEs have different characteristics in two basic respects. First, EMNEs may face more critical legitimacy challenges in host countries, especially in countries with more stringent rules $[46,90]$. Second, it is argued that EMNEs have a competitive advantage in social and environmental adaptation in other emerging and/or developing countries because of the similar institutional environments of the home-country and host-country [27,91], as well as the specific experience and expertise in countries with lax environmental standards [92,93]. These firm-specific attributes may substantially influence EMNEs' green governance response patterns.

\subsection{The Resource-Based View of Emnes' IB Strategies}

The RBV underscores the idea that every firm possesses a unique bundle of resources and capabilities that influence its strategic choices and, ultimately, its competitive advantages $[79,94]$. One prominent theoretical paradigm extending from the RBV strand is the natural resource-based view (NRBV) proposed by Hart [95]. He argues that "waste minimization" is a "specialized capability" that simultaneously facilitates pollution reduction and cost savings. Since environmental regulations emerged as important barriers to international corporate investment [96], strong environmental capabilities play a significant role in successfully meeting certain environmental standards of foreign countries. Previous findings suggest that the relationship between environmental regulations and an MNE's location decision is actually more complex than it was previously thought to be, because a firm's environmental capabilities may intervene as a moderating influence [10]. Madsen found that international automobile manufacturers with stronger environmental capabilities locate to more environmentally stringent countries, while firms with weaker environmental capabilities locate to countries where environmental regulation is laxer [10]. Moreover, environmental capabilities constitute the utilization of bundles of resources and routines that allow a firm to minimize its environmental impact. Such environmental resources may include pollution prevention experience, environmentally benign technologies, environmental accounting systems, environmental engineering expertise, and employee commitment to protecting the natural environment [97,98]. Consequently, stronger environmental capabilities can also help MNEs adopt more proactive environmental management practices in host countries [79].

Earlier studies have shown that technological capabilities in particular play a fundamental role in investment location choice and superior MNE international performance $[99,100]$, because technological capabilities enable firms to be more creative [101]; accelerate new product development [102]; expedite the commercialization of such new products [103]; and, subsequently, attain the first-mover advantage [104]. Lei and Chen observed that Taiwanese firms with stronger technological capabilities were located in more developed regions, while others were located in less developed regions [105].

Given the common lack of strong environmental capabilities and technological capabilities among EMNEs, studies of internationalization may depict such firms as stereotypical units that possess no valuable advantages relative to AMNEs. Such a stance is contradicted by numerous examples. For instance, the Chinese company China General Nuclear Power Group has high-quality environmental and technological skills and expanded rapidly in Europe's nuclear power 
sector [106,107]. The Indian company Hindalco has developed a range of innovative technologies and globally promotes its environmental capabilities and technological capabilities [108]. However, most EMNEs still lack strong environmental capabilities and technological capabilities compared with their counterparts with advanced economies $[109,110]$. As a result, in global markets, some EMNEs play the roles of environmental and technological late-followers who might be hindered by environmental standards and legitimacy problems in their global business expansion [79]. Some EMNEs can behave as environmental and technological leaders with valuable and competitive advantages, which can be deployed through global expansion. However, the existing research has not sufficiently explored this phenomenon, which limits our understanding of EMNEs' global IB strategy diversity.

\section{Materials and Methods}

\subsection{Research Design}

This research was carried out in three progressive and interrelated studies to build up a more complete understanding of EMNEs' IB strategies. First of all, in order to extend our understanding of green governance, we argue that there is a need for a more fine-grained typology of green governance contexts. The reasons for this are as follows. On one hand, the green governance context is an integral and crucial part of the governance environment $[1,111,112]$. EMNEs are exposed to diverse macroeconomic opportunities and threats that affect their decisions and businesses [113-116]. More specifically, the directionalities and degrees of policies and regulations in tax rates, governmental subsidies, administrative efficiency, environmental regulation, and environmental enforcement affect their input costs and output prices [61-64,117], thus affecting the location choice and response patterns. On the other hand, previous research has roughly classified green governance contexts across the world into developed and developing countries e.g., [10], rich and poor countries e.g., [45], and north and south countries e.g., [46]. These simple dichotomies obscure the rich connotations of green governance [1,21], overlook the progress made by some countries in green governance [47-49], and cause ambiguity for scholars and managers. Thus, through the perspectives of growth priority and green priority, we first pragmatically recategorized green governance contexts along two dimensions: FDI policy and environmental regulation. The two dimensions can well-represent different situations and combinations of growth priority and green priority. The green governance contexts are divided into four quadrants. Then, we employed multiple case studies of 11 Chinese MNEs operating in 11 countries belonging to these four quadrants. Qualitative exploratory research is particularly effective at opening the "black box" of what underlies a phenomenon and extending our understanding of the "how" and "why" questions [118]. In particular, the use of multiple case studies can provide rich contextual descriptions and reveal complex relationships [119]. The analysis allows generalized trends across cases to emerge from unique patterns in individual cases [120] and elucidate whether causes are related to outcomes in an invariant, necessary, and sufficient relationship (variance model) [121]. The variance model shows us how antecedent variables predict the outcome variables [122], thus helping us to draw new theoretical insights on the basis of the practices of sample firms. Finally, through case analysis, the key findings are presented and discussed in the results and discussion sections.

\subsection{Sampling Criteria}

We chose 11 Chinese MNEs operating in 11 different countries. These firms are constrained in some pollution-intensive and environmentally regulated industries, such as the mining, chemical, and infrastructural sectors. One reason for this tendency is that natural resource and infrastructure project sectors are likely to attract more investment by EMNEs [123]. Another reason is that MNEs in the pollution-intensive industries, specifically those engaged in mining, are under intense pressure and scrutiny from governmental and societal forces, which have formed in response to concerns about the social and environmental impacts of operations [124-127]. Thus, firms in these industries are more likely to embed a greater degree of social responsibility into their management strategies than those 
operating in less regulated industries [128]. The 11 respective countries are the natural result of firm selection rather than deliberate choices. In a multiple-case study, the selection of the cases should follow a replication rather than mass sampling logic $[119,120]$. In our study, each case was carefully selected so that it either predicts similar results (a literal replication) or predicts contrasting results but for anticipatable reasons (a theoretical replication) [119]. Two or three cases were distributed in the same green governance context to validate the literal replication. Comparing two to three cases in the same green governance context can demonstrate the theoretical replication. Therefore, 11 sample companies are appropriate and can provide substantial support for different IB strategies in the four proposed different green governance contexts.

Due to increased governmental and societal pressure, pollution-intensive companies have been actively innovating in the field of social responsibility to address the various sustainability challenges of their operations more proactively [129]. However, much evidence suggests that MNEs often approach ethical issues differently in different institutional contexts [130,131]. For instance, many studies have revealed that there is a trend for mining MNEs operating in developed countries to incorporate an ethical approach to corporate legitimacy, transcending profit-making and compliance with laws $[6,132,133]$. Some scholars have indicated that MNEs operating in underdeveloped countries generally find that regulatory environments are less sophisticated than those in their home countries; thus, they have a propensity to behave unethically in these countries $[27,91,134]$. We paid special attention to selecting informants with adequate experience in international investment and overseas management. Following Yin [119], two criteria were used to select the sample firms and interviewees. First, the length of operation in the corresponding host countries of our research should be sufficient for us to collect meaningful information for our study. Therefore, we selected firms that have been operating in the host country for at least three years to allow us to explore the issues related to our research. Second, the interviewees need to be familiar with the decision-formulating process of choosing the investment location and with the management of their subsidiary (-ies) in the corresponding host countries. Thus, the most appropriate participants were those who (1) worked as current or ex-senior managers of the subsidiary (-ies) in the corresponding host countries, (2) worked at the international investment department of corporate headquarters, or (3) were responsible for international operations. Detailed characteristics of our case study firms are presented in Table 1. 
Table 1. Sample description.

\begin{tabular}{|c|c|c|c|c|c|c|}
\hline Sample Firms & Ownership & Founded in & Business Description & $\begin{array}{l}\text { Approximate Sales in } \\
2017 \text { (Billion US dollars) }\end{array}$ & Host Country & $\begin{array}{l}\text { Years of Respective Hos } \\
\text { Country Operation }\end{array}$ \\
\hline $\mathrm{A}$ & $\mathrm{SOE}$ & 1996 & Mining and refining of gold, silver, copper & 7.61 & Argentina & 5 years \\
\hline B & POE & 2001 & Coal mining, coal washing, and sales & 1.88 & Mongolia & 12 years \\
\hline $\mathrm{C}$ & $\mathrm{SOE}$ & 1998 & $\begin{array}{l}\text { Oil and gas exploration \& production, refining \& } \\
\text { chemicals, natural gas \& pipelines, and } \\
\text { marketing \& trading }\end{array}$ & 300.88 & Venezuela & 16 years \\
\hline $\mathrm{D}$ & $\mathrm{SOE}$ & 1998 & $\begin{array}{l}\text { Oil and gas exploration, production, storage, } \\
\text { and transportation }\end{array}$ & 352.24 & Nigeria & 9 years \\
\hline $\mathrm{E}$ & $\mathrm{SOE}$ & 2001 & $\begin{array}{l}\text { Mineral resources development, nonferrous metals } \\
\text { smelting and processing, and related trading }\end{array}$ & 46.27 & Peru & 10 years \\
\hline $\mathrm{F}$ & POE & 1992 & $\begin{array}{l}\text { Rubber chemicals production, automotive } \\
\text { tire production }\end{array}$ & 2.74 & Thailand & 3 years \\
\hline G & $\mathrm{SOE}$ & 1993 & Hydropower engineering and construction & 12.46 & Brazil & 5 years \\
\hline $\mathrm{H}$ & $\mathrm{SOE}$ & 2006 & $\begin{array}{l}\text { Design and construction of transportation } \\
\text { infrastructure, dredging and heavy } \\
\text { machinery manufacturing }\end{array}$ & 72.10 & Kenya & 5 years \\
\hline I & SOE & 1976 & $\begin{array}{l}\text { Coal mining and sales, coal chemicals production } \\
\text { and sales }\end{array}$ & 29.73 & Australia & 14 years \\
\hline $\mathrm{J}$ & $\mathrm{SOE}$ & 1982 & $\begin{array}{l}\text { Oil \& gas exploration and development, engineering } \\
\text { and technical services, refining and sales }\end{array}$ & 27.82 & Canada & 5 years \\
\hline K & SOE & 1994 & $\begin{array}{l}\text { Nuclear engineering, nuclear plant construction } \\
\text { and operation }\end{array}$ & 12.70 & United Kingdom & 6 years \\
\hline
\end{tabular}

Sample $=11$ firms. SOE is the abbreviation for State-Owned Enterprise. POE is the abbreviation for Private-Owned Enterprise. 


\subsection{Data Collection and Analysis}

Recategorizing the green governance context was our starting point. Governments need to achieve a balance between attracting foreign investment (for economic development) and protecting the local environment (for environmental sustainability). Therefore, in our study, we argue that the new and more fine-grained typology of the green governance context can be categorized along two dimensions: FDI policy and environmental regulation.

"Governance" is notoriously difficult to measure, so formal evaluations and analysis are scarce [135]. To illustrate our green governance typology for countries, we drew on measures available in the World Economic Forum's (WEF's) Executive Opinion Survey (EOS) 2011-2016 [136-138] related to FDI policies and environmental regulations. On an annual basis, this survey gathers top corporate executives' assessment of countries' FDI policy attractiveness and environmental regulation stringency. The advantage of this survey is that it measures the attractiveness of FDI policy and stringency of regulation that businesses experience in practice. For example, a country can have very strict environmental laws, but they may not be effectively enforced. Further into the paper, we use the clustering method to map out possible quadrants of the green governance context.

To measure the degree of FDI policy attractiveness, we used the answer to the question included in the EOS: "To what extent do rules governing foreign direct investment (FDI) encourage or discourage it? $(1=$ strongly discourage FDI; $7=$ strongly encourage FDI)". We summed and averaged the scores of each country for the period between 2011 and 2016. Countries with missing scores in any year of this period were eliminated. To measure the degree of environmental regulatory stringency (for the environmental regulation stringency dimension), we used the answers to two questions included in the EOS: (1) "the stringency of environmental regulation in your country is: $(1=$ very lax; $7=$ among the world's most stringent)"; (2) "the enforcement of environmental regulation in your country is: ( 1 = very lax; 7 = among the world's most rigorous)". This dimension was operationalized by summing and averaging the two questions into one measure by weighting each question by a factor of 0.5. After eliminating countries with missing scores, we calculated and ranked each country's total score from high to low between 2011 and 2016. Based on the criteria, we obtained the average values for 127 countries in the two dimensions.

We relied on interviews, archival data, and second-hand materials (media coverage, third-party academic and business reports) as our firm data sources. Multiple data sources can be used to triangulate the data and improve the accuracy of the emerging picture [139]. We conducted one round of pilot interviews and two rounds of formal face-to-face and phone interviews from March 2015 to January 2018 to avoid inappropriate questions (Here, the inappropriate questions indicate offensive questions and some questions related to the dark sides of firms. These questions may engender antipathetic and strong emotions of interviewees and may cause the interviews to be terminated.) These questions are hard to ask directly, but such questions can help us to gain more complete information and better understand firms' antecedents and practices. The time gap allowed us to solve this particular challenge. The pilot interviews assisted in refining the semi-structured interview and enhancing mutual trust between interviewers and interviewees. The conversations and materials were limited to scientific research, with the promise of anonymity. During the interviews, there was no attempt to "lead" the participants or avoid offensive words, such as dirty investor, beggar thy neighbor, and neo-colonialist. Broad questions were posed during the interviews. These efforts allowed interviewees to gradually and freely mention the negative aspects of these firms. As the retrospective interviews concerned relatively recent facts [140], the last round of interviews was conducted after 2017. With the time gap, enriched information increasingly emerged. The interviews were conducted in Mandarin and were recorded, with most interviews lasting 45-120 min in length. Interview notes were transcribed within $24 \mathrm{~h}$ after each interview to minimize information loss.

Interview data can, at times, be problematic due to an interviewee's attempts to conceal or distort reality [141], which is a well-documented aspect of the pollution-intensive industry's response to environmental issues. Consequently, in this study, we made several efforts to minimize such 
distortion. First, before, during, and after each interview, we triangulated and verified interviewee statements with each firm's most recent environmental reports and web pages, their latest annual reports, and any relevant publicly available submissions to the government. These documents enabled us to probe, specify, and corroborate evidence acquired from the interviews. Second, we selected at least two firms in each green governance context, which allowed us to compare statements across different firms. Third, we did not take interviewee statements at face value. Instead, we critically evaluated each statement by asking numerous follow-up questions that required the interviewees to give detailed reasons for their investment location choice and provide actual examples of their firms' local environmental management practices.

To document the data collected by interviews, we referred to the guidelines recommended by Yin $[119,142]$. First, we used multiple sources of evidence in a manner that encourages convergent lines of inquiry and establishes a chain of evidence. Besides interview data, we also collected archival data from several sources, including company websites, internal periodicals, WeChat (the major Chinese social software) official accounts, and historical documents. In addition, we referred to secondhand materials related to the sample firms, including media coverage and third-party academic and business reports, for the purpose of triangulating the data and improving the construct validity. These data complement the information from our interviews and facilitate an in-depth understanding of sample firms' IB strategies. Second, we had key informants review the draft case study reports until any disagreement was settled by further evidence.

Because firms' Corporate Social Responsibility (CSR) and environmental practices cannot be easily observed and validated $[79,143]$, we conducted a content analysis to evaluate firms' environmental capabilities and technological capabilities. The evaluation criteria are based on previous studies of environmental capabilities $[10,79,98]$ and technological capabilities $[28,102,103]$. To improve the validation, we relied on independent third-party reports and media coverage to verify related content and materials. The key sources of each firm's environmental capability and technological capability are illustrated in Table 3. To enhance our accuracy of evaluation, we invited related professionals to jointly evaluate each firm's capabilities—which are labeled as "low" or "high" —and give explanations. We studied the sample firms' similarities and differences in their green governance response patterns according to each interview transcript. We merged similar codes into the same first-order category and continued coding the transcripts in this manner until no further distinct or shared patterns could be detected. Alongside the development of first-order categories, we identified linkages among these categories that could lead to the development of more theoretically oriented second-order themes. We then distilled the categories into more aggregated themes. Finally, we aggregated these themes into different clusters.

As recommended by Yin [119,142] and Eisenhardt [120], we assessed the reliability and validity of the study. First, separate within- and cross-case analyses were carried out using pattern-matching and explanation-building analytic strategies [119]. For instance, to control for alternative explanations at the firm level, a method of pattern matching was applied to establish whether the cross-contextual pattern of green governance conformed to the pattern that these alternative factors would suggest. If the theoretically derived pattern did not conform to the actual pattern, the alternative explanation could be ruled out. Second, to address the reliability problem, we documented each step of the study in detail as though being watched over our shoulders [142]. Third, to alleviate the influence of subjectivity in the coding process, three researchers independently performed the coding process. Disagreements were resolved through research group discussions according to construct definitions and, sometimes, additional information collected from key informants, rather than the rigid rule dictating that the minority is subordinate to the majority. Because the interaction between MNEs and the green governance context is a complex, dynamic, and interdependent process, we present fairly long quotes from interviews as evidence to facilitate the emergence of complex relationships. In addition, many of the quotes provide evidence for our propositions and discussions. 


\section{Results}

\subsection{Recategorizing Green Governance Context: An Illustrative Analysis}

To illustrate how the green governance context may be categorized into the proposed quartered division, we began by operationalizing FDI policy and environmental regulation and then conducted cluster analysis of the countries identified by WEF's EOS. To identify clusters, we conducted cluster analysis using the K-means clustering method. Cluster analysis refers to the process of grouping a collection of physical or abstract objects into multiple classes of similar objects. The K-means is a classic partitioned cluster analysis method that is well-known for its efficiency in clustering large-scale data sets. The data were classified into $\mathrm{K}$ clusters, and each cluster was given a category center. The Euclidean metric was selected as the criterion of similarity and distance, and the sum of squares of the distance between the points in each class to the center of the cluster was calculated to minimize the sum of squares within each cluster [144]. We implemented K-means clustering using scikit-learn in Python 3.6. Our initial centers for the four groups based on pairs (standardized FDI score, environment score) were assigned as follows: the low-low cluster was initialized at $(2,2)$, low-high at $(2,6)$, high-low at $(6,2)$, and high-high at $(6,6)$. Vertically, it was clustered by the average scores of countries' FDI attractiveness in WEF's EOS 2011-2016; for compositional and graphical simplicity, we labeled the matrix "growth priority". Horizontally, it was clustered by the average scores of countries' environmental regulatory stringency of WEF's EOS 2011-2016, and we labeled this matrix "green priority" (Figure 1).

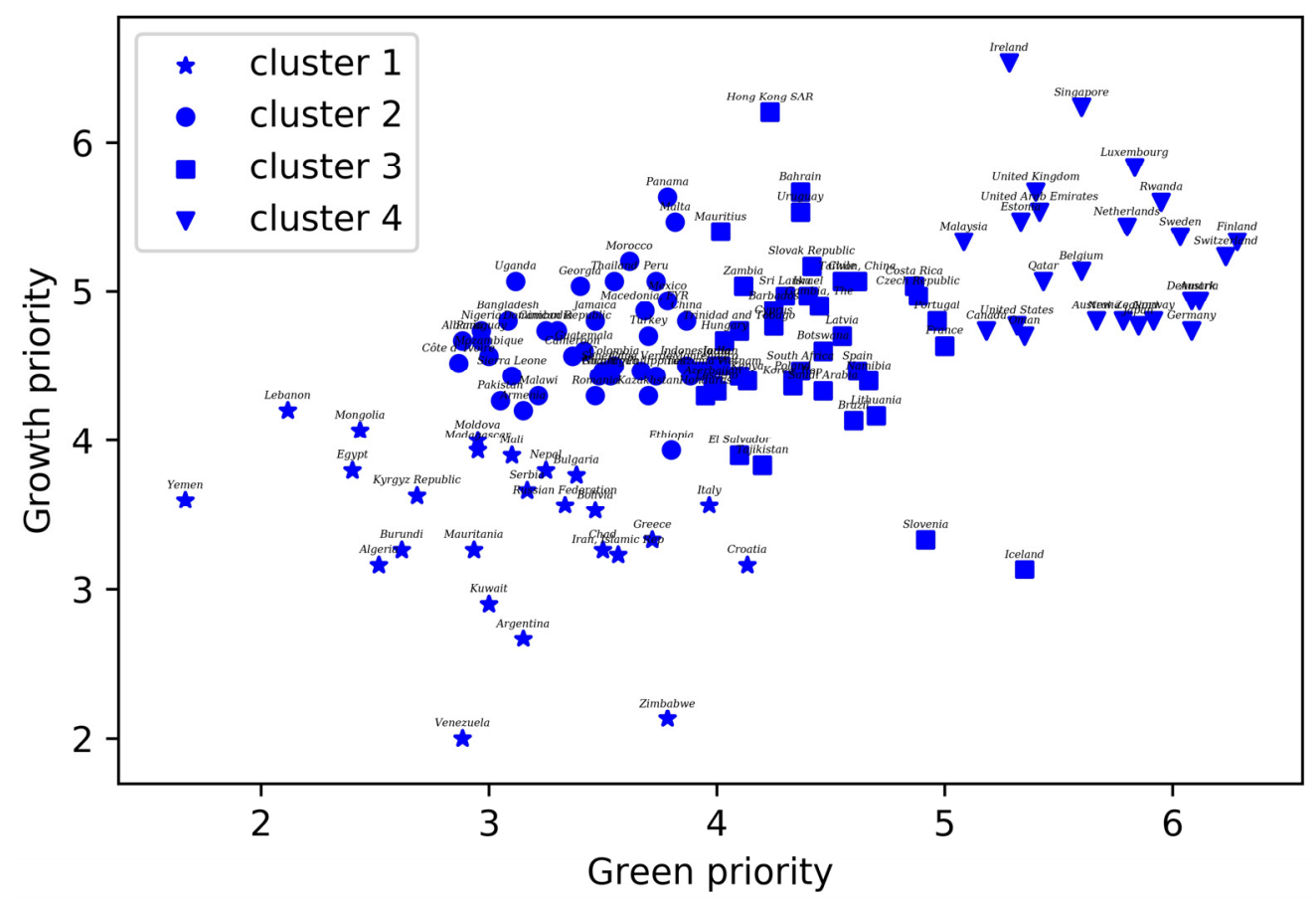

Figure 1. Cluster analysis of green governance context.

Figure 2 reports the stringency of environmental regulations and enforcement of the 11 respective countries in which our sample firms are working. Comparing the median and mean values of 127 countries reveals that the values for Mongolia, Venezuela, Nigeria, Argentina, Thailand, and Peru are lower than the mean and median values. Therefore, we classified these six countries as lax environmental countries. The values for Kenya, Brazil, Canada, the United Kingdom, and Australia are higher than the mean and median values. Therefore, we classified these five countries as strict environmental countries. Canada, the UK, and Australia have always been known for very strict environmental regulations. The UK enacted the first modern environmental regulation, the Clean 
Air Act, as early as 1956, and this law formed an important impetus to modern environmental legislation. Kenya and Brazil vigorously promote green development and have increased their degree of environmental legislation and enforcement in recent decades. Their efforts address environmental degradation [48] and have gradually narrowed the gap between their environmental approaches and those of advanced economies. However, the environmental regulations of Argentina, Mongolia, Venezuela, Nigeria, Peru, and Thailand demonstrate a lower level of stringency, and the enforcement is often crippled by corruption and a lack of monitoring.

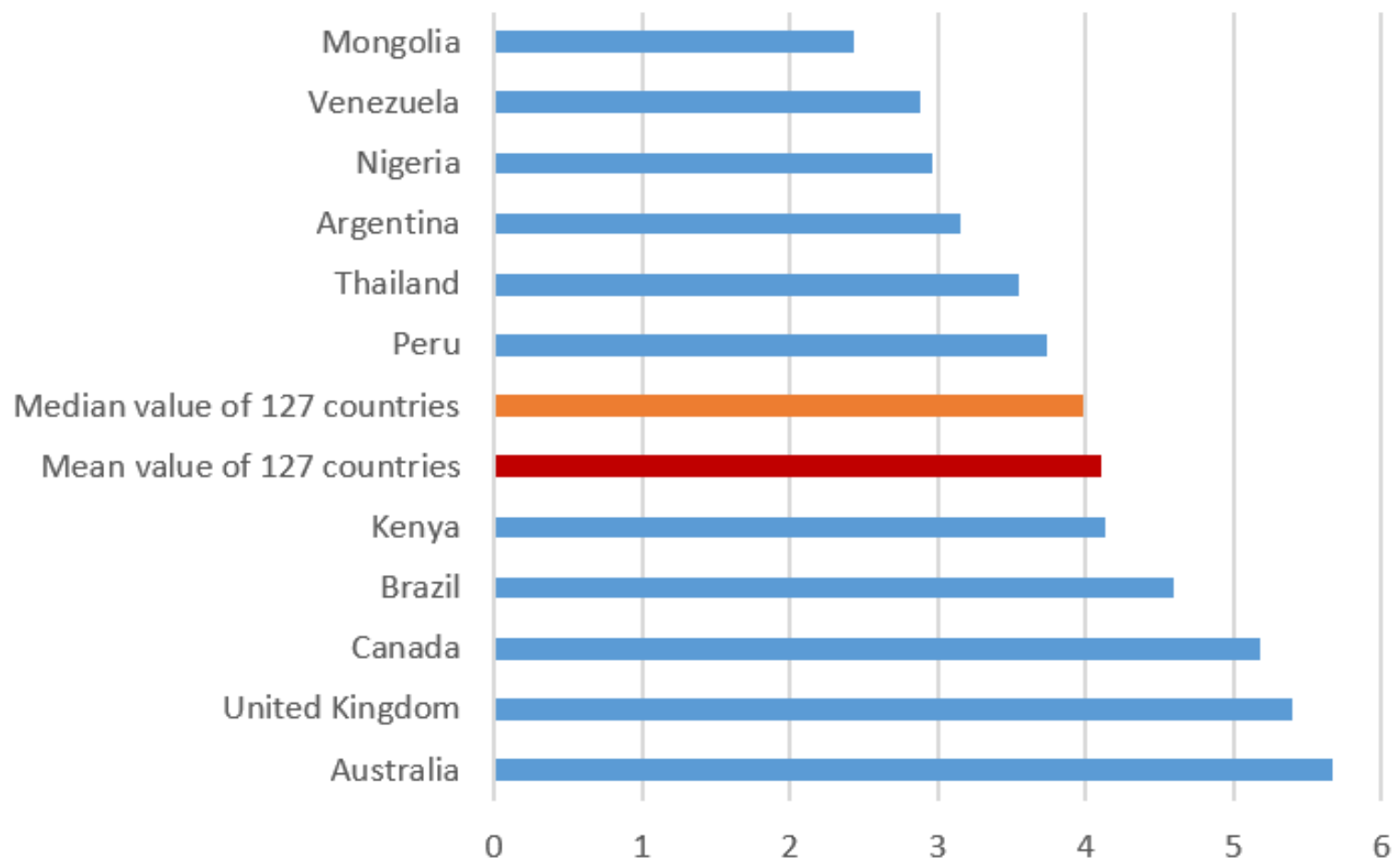

Figure 2. The stringency of environmental regulations and enforcement of 11 countries.

Most of our sample firms are mining companies and their respective countries are natural resource endowed. In the mining sector, a financial guarantee is a popular practice that is used for environmental reclamation and rehabilitation after the mine's closure. It is also an important dimension of environmental regulation. Governmental requirements for financial assurance will significantly affect MNE's compliance cost. Thus, we paid special attention to the legal provisions of financial guarantees in the 11 respective countries in which our sample firms are working. Table 2 reports the legal provisions on financial guarantees in 11 respective host countries. The result of this dimension is basically consistent with Figure 2 . 
Table 2. The legal provisions on financial guarantees in 11 respective host countries.

\begin{tabular}{cl}
\hline Countries & \multicolumn{1}{c}{ Legal Provisions on Financial Guarantees } \\
\hline Argentina & National Law on Environment (2002), Federal Mining Agreement (2017) \\
\hline Mongolia & Not known at this time \\
\hline Venezuela & Not known at this time \\
\hline Nigeria & Minerals and Mining Act (2007) \\
\hline Peru & Law Regulating the Closure of Mines (2003), National Guidelines for the Elaboration of \\
& Mine Closure Plans (2006) \\
\hline Thailand & Minerals Act (2017) \\
\hline Brazil & Mining Regulation Norm (2001), Plan for Rehabilitation of Degraded Areas (2001) \\
\hline Kenya & $\begin{array}{l}\text { Mining Bill (2014), National Environmental and Coordination Act (1999), Environmental } \\
\text { Regulations (2003) }\end{array}$ \\
\hline \multirow{2}{*}{ Australia } & $\begin{array}{l}\text { Environmental Protection Act (1994), Environmental Protection Regulation (2008), Mining } \\
\text { Rehabilitation Fund Act (2012), Mining Rehabilitation Fund Regulations (2013) Guidelines } \\
\text { for Preparing Mine Closure Plans (2011, 2015), Mining Act (2015) }\end{array}$ \\
\hline \multirow{2}{*}{ Canada } & $\begin{array}{l}\text { Canadian Environmental Protection Act (1999), Mining Act (2009), Canadian } \\
\text { Environmental Assessment Act (2012) }\end{array}$ \\
\hline \multirow{2}{*}{ UK } & $\begin{array}{l}\text { Mines and Quarries Act (1969), Petroleum Royalties and Continental Shelf Act (1989), } \\
\text { Environmental Protection Act (1990) Coal Industry Act (1994), Environment Act (1995), } \\
\text { Petroleum Act (1998), Landmines Act (1998) }\end{array}$ \\
\hline
\end{tabular}

We could not find any legal provisions for Mongolia and Venezuela on financial guarantees at this time. Financial guarantees present in various forms, such as bonds, charges, deposits, indemnities, mortgages, or trusts. Generally speaking, in Brazil, Kenya, Australia, Canada, and the UK, the legal provisions on financial guarantees are more stringent and systematic than in Argentina, Nigeria, Peru, and Thailand. Moreover, the permitting, inspection, enforcement, and education processes of the former countries can be effectively implemented. Although the latter countries have enacted legislation on financial guarantees, there remain many problems and challenges with these legislations. First, the timing is flexible, so mining companies can provide financial guarantees in the late stage of their operation; second, mining companies can provide a small number of financial guarantees; third, the funds are disorganized, and sometimes the funds are used by governments for other purposes; and fourth, there is a lack of diverse financial guarantee mechanisms. On the contrary, in the former countries, especially in Australia, Canada, and the UK, mine closure issues are an important consideration during the assessment process for mining proposals; financial guarantees are required by central and local jurisdictions, under overall supervision, and strictly implemented. We also note that some countries have strengthened their legislation on financial guarantees in recent years, such as Peru. This trend will undoubtedly continue.

Figure 3 reports the attractiveness of the FDI policies of the 11 respective countries in which our sample firms are working. Comparing the mean and median values of 127 countries reveals that the values for Venezuela, Argentina, Mongolia, Brazil, and Kenya are lower than the median and mean values of 127 countries. Therefore, we classified the FDI policies of these five countries as unattractive. The values for Nigeria, Canada, Australia, Thailand, Peru, and the United Kingdom are higher than the mean and median values. Therefore, we classified the FDI policies of these six countries as attractive. 


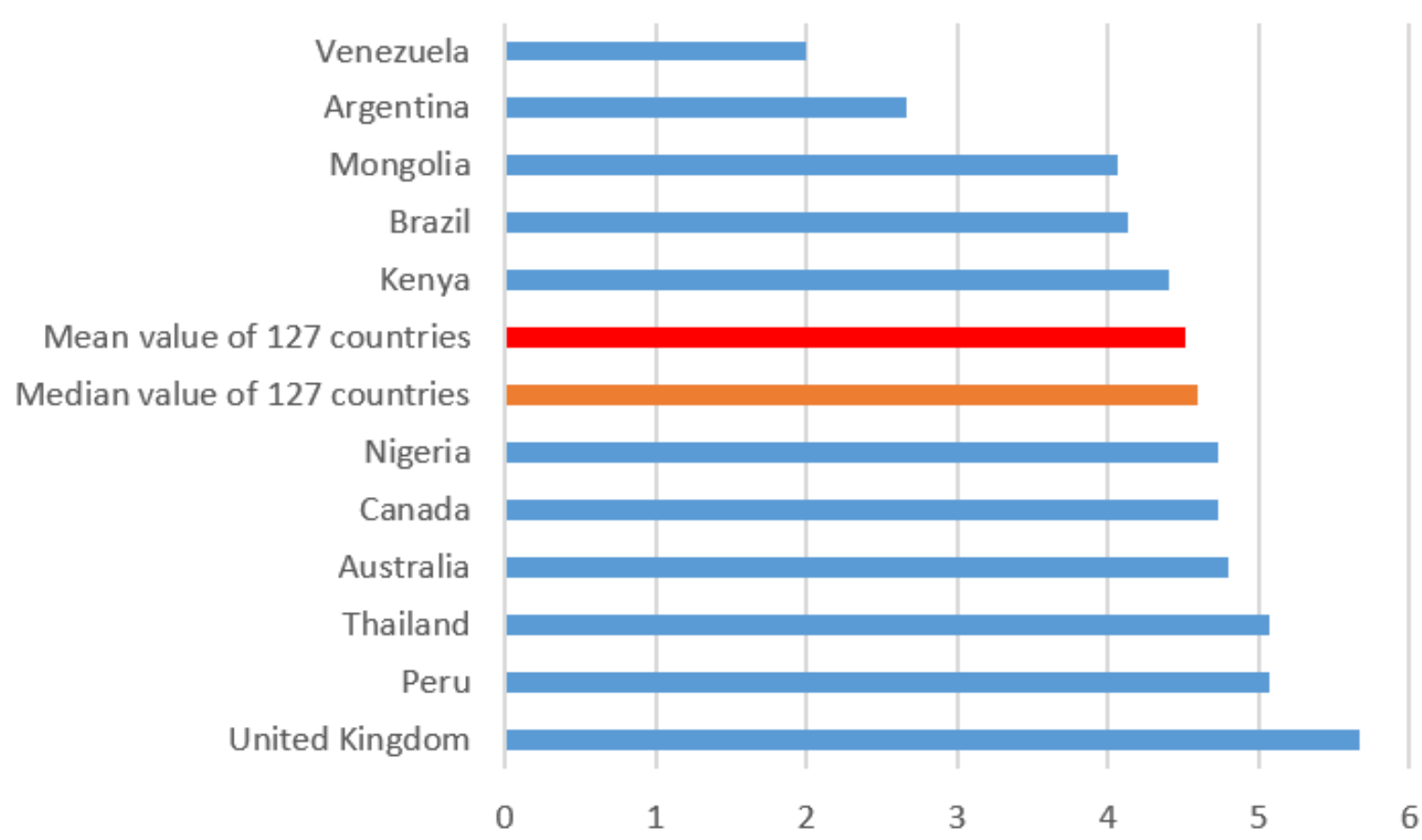

Figure 3. The attractiveness of FDI policies of 11 countries.

We used a two-by-two matrix to present the results of clustering more clearly. The four cluster groups in Figure 1 can be matched one-to-one to the four quadrants in Figure 4. According to the cluster groups' membership, the countries are generally categorized into the quadrants. Our sample firms and the four kinds of green governance contexts are more clearly presented in Figure 4.

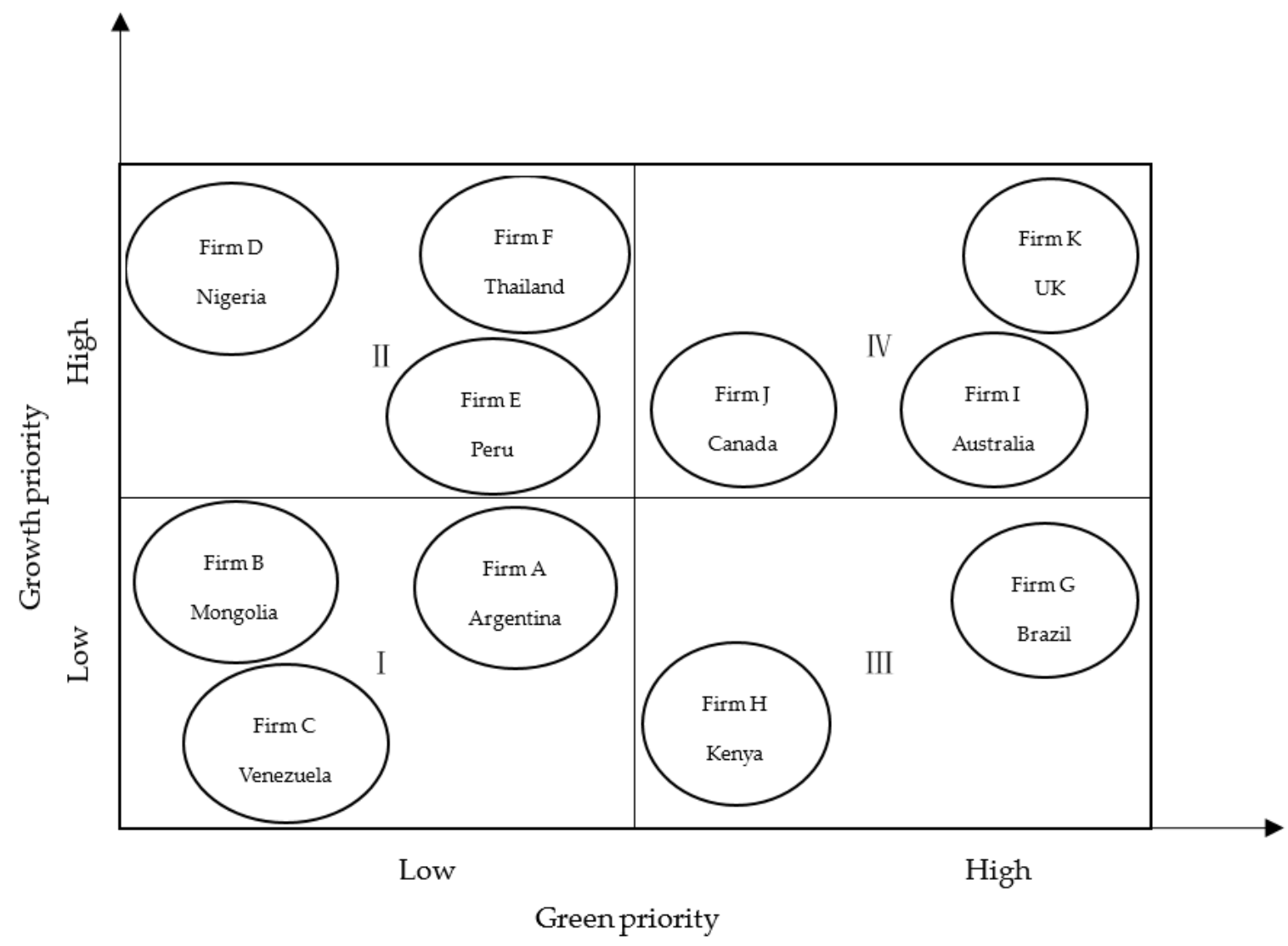

Figure 4. Sample firms in different green governance contexts. 
Quadrant I (lower left) identifies a kind of green governance context with little FDI appeal and lax environmental regulation. Some countries, like Argentina, Mongolia, and Venezuela, would fit this description. Foreign investors in these countries are routinely viewed as persona non grata. The hostility of the host country's investment environment makes it hard for foreign firms to do business there. Moreover, they are usually economically disadvantaged and commonly do not have the resources or a certain level of technological progress to legislate and implement stringent environmental regulations $[145,146]$.

Quadrant II (upper left) presents a situation in which countries value FDI more than environmental quality. Thailand, Nigeria, and Peru are examples of countries with this context. They are easily labeled "pollution havens" because of weak environmental regulations and limited political will for strict enforcement [47]. Their green efforts have been eclipsed by a focus on economic growth measures, especially FDI attraction incentives. In some countries, foreign investors can even enjoy more preferential policies than local firms do.

Quadrant III (lower right) shows the sort of context characteristic of countries that value environmental preservation more than foreign investment, such as Saudi Arabia, Brazil, and Kenya. Countries in this cell make efforts to prioritize environmental issues over economic concerns. They often have impressive environmental legislation in place and strong legal enforcement. However, the foreign investment climate in these countries is not warm. They have some legal rigidity and slow policy implementation for foreign investors, such as banning foreign investment in certain economic sectors and geographical regions, leaving a high proportion of government contracts to local firms, requiring a large proportion of natives to be employed, etc.

Quadrant IV (upper right) exhibits the kind of green governance context for countries that put a high premium on foreign investment and environmental protection simultaneously. Countries in this cell are more likely to have highly advanced economies, such as the United States (US), the United Kingdom, Australia, and Canada. On the one hand, they compete actively and have incentives to attract FDI [147]. On the other hand, they are used to having high levels of environmental laws and standards and tend to take a proactive approach to environmental protection [148]. A small number of countries in this cell, such as the United Kingdom and Canada, have some of the most stringent environmental regulations in the world. The stylized typology outlined in Figure 4 indicates that the green governance context can be differentiated within a broad spectrum associated with FDI policy and environmental regulation dimensions. However, our cluster analysis in Figure 1 indicates that the two extreme categories (e.g., high green priority/low growth priority and low green priority/high growth priority countries) are very sparsely populated. Most of the countries seem to be located within a moderate area for both the green priority and growth priority. This highlights the possibility that our chosen dimensions may be interdependent. Indeed, the history of countries' development is a testament to the fact that governments often strategically set environmental regulatory standards to attract investment [10] or use environmental regulations to keep foreign investors away. This conjecture opens up an interesting area for future research that may be focused on the co-evolution of FDI attraction and environmental protection and its effects on business strategy.

\subsection{The Antecedents of Firms' Location Choice}

According to our findings, environmental capabilities and technological capabilities played important roles in the antecedents of the sample firms' location choice. The sample firms have been leveraging their environmental capabilities with the objective of gaining a competitive advantage through an enhanced reputation, a reduction in production costs, and employee commitment. They have employed their technological capabilities to obtain a competitive advantage through R\&D acceleration, innovative products, and first-mover actions. On the basis of the interviews and documents and with the help of related professionals, we evaluated the sample firms' environmental capabilities and technological capabilities. Table 3 presents the role of environmental capabilities and technological capabilities in the firms' location choice, the evaluation resource, and results. 
Table 3. The capabilities evaluation and the role in location choice.

\begin{tabular}{|c|c|c|c|}
\hline $\begin{array}{l}\text { Firm-Specific } \\
\text { Capabilities }\end{array}$ & Evaluation Result & Key Sources & Competitive Advantage \\
\hline $\begin{array}{l}\text { Environmental } \\
\text { capability }\end{array}$ & $\begin{array}{l}\text { High capability: sample } \\
\text { firm G, H, I, J, K } \\
\text { Low capability: sample } \\
\text { firm A, B, C, D, E, F }\end{array}$ & $\begin{array}{l}\text { Environmental Impact Assessment report, } \\
\text { Energy quarterly newsletters, monthly } \\
\text { newsletters, ISO } 14001 \text { report, CSR annual } \\
\text { reports, Sustainability annual reports, } \\
\text { sustainability best practice brochures, } \\
\text { official website news, media coverage, } \\
\text { interview content }\end{array}$ & $\begin{array}{l}\text { Lower the } \\
\text { regulatory cost } \\
\text { Corporate reputation } \\
\text { Better relationships } \\
\text { Employee commitment } \\
\text { Cost saving } \\
\text { Green product } \\
\text { Energy savings }\end{array}$ \\
\hline $\begin{array}{l}\text { Technological } \\
\text { capability }\end{array}$ & $\begin{array}{l}\text { High capability: sample } \\
\text { firm A, B, C, H } \\
\text { Low capability: sample } \\
\text { firm D, E, F, G, I, J, K }\end{array}$ & $\begin{array}{l}\text { R\&D center reports, human resource } \\
\text { reports, technological innovation report, } \\
\text { patents, official website news, media } \\
\text { coverage, interview content }\end{array}$ & $\begin{array}{l}\text { Better originality } \\
\text { R\&D acceleration } \\
\text { First mover } \\
\text { Innovative product } \\
\text { Future forecast }\end{array}$ \\
\hline
\end{tabular}

In our interviews with the sample firms' managers, we found that most of them viewed the host countries' environmental standards as an entry barrier. Furthermore, the firms' environmental capabilities and technological capabilities were sometimes a determinant of the firms' location choices. Here are some statements quoted from the interviews.

“At first, we didn't take account of Mongolia as our investment destination because of bad investment climate. We want to invest in Australia, but our environmental capabilities cannot meet Australian environmental standard. The high proportion of financial guarantee in Australia is also a heavy burden for us." (Firm B, Mongolia)

"We need to invest in countries with rapid economic development, such as Peru, to guarantee our profit [ ... ]. In recent decades, the local competitors have been growing fast, and many of them are artisanal and small-scale companies. They use rudimentary techniques resulting in serious environmental damages. However, local communities historically rely on them because of their contributions to rural unemployment and poverty alleviation. With the aid of local communities, they evade environmental regulation and take no responsibility for their pollution. We need to take some of our revenue to the financial guarantee deposit, but they don't." (Firm E, Peru)

"Brazilian hydropower market is very big [ ... ]. However, there are much discrimination against foreign investors in access to government-financed projects. Fortunately, because of rigid environment laws, the competition isn't very strong. Not so many companies can meet the strict and complex environmental regulation." (Firm G, Brazil)

“The British nuclear projects are growing fast $[\ldots]$. We are not worry about the extra compliance cost because the British treat us and its local business equally [ ... ]. Although the environmental standard in UK is very high, we can meet the requirement $[\ldots]$. Our technology is globally leading, and its safety and efficiency has been proved in many countries. Our technology and technicians help us better capture the growing business opportunities in UK." (Firm K, UK)

From these statements, some main points have emerged. A lack of environmental capabilities has resulted in firms being trapped in lax environmental regimes, and it is difficult to escape. They are confronted with intense competition because of a growing number of competitors. On the contrary, firms equipped with strong environmental capabilities tend to invest in countries with strict environmental regulations that can filter out companies with weak environmental capabilities. They would have less competition and a better performance. In this respect, firms that possess strong environmental capabilities could organize their portfolio for deployment in countries where 
they could exploit their advantages of environmental capabilities [79]. Our findings provide evidence that environmental capabilities enable EMNEs to pass through the entry barrier as well. Friendly FDI policies facilitate host countries' economic growth and generate great business opportunities for foreign investors. Technological capabilities enable firms to be more creative [101]; accelerate product iteration [102]; quickly meet the market demand [103]; and, subsequently, attain a first-mover advantage [104]. Countries that prioritize economic development normally witness a substantial increase in national wealth and personal income, and then stimulate national and personal consumption, which would lead to diverse market needs and picky consumers $[149,150]$. Therefore, strong technological capabilities help firms become more competitive and better harness the host countries' growth opportunities. On the basis of these arguments, we present Proposition 1a and Proposition 1b.

Proposition 1a. EMNEs with strong environmental capabilities are more likely to invest in countries with a higher level of green priority.

Proposition 1b. Proposition 1b: EMNEs with strong technological capabilities are more likely to invest in countries with a higher level of growth priority.

\subsection{Four Types of Green Governance Response Patterns}

As four kinds of green governance contexts are presented and validated in Section 4.3, we note that the sample MNEs adopted different response patterns under different green governance contexts. Previous studies have shown that MNEs usually adopt different environmental approaches under different regulatory situations $[79,80]$. However, most of these studies only consider the "pull" effects from stakeholders and overlook the "push" effects from the firms themselves. We aggregated these record manuscripts into four clusters and classified them as the defensive approach, functional approach, accommodative approach, and proactive approach, indicating the four different types of green governance response patterns. Each of these patterns represents a specific configuration of both the motives linking profit-maximization and risk calculations to a longer-term normative sustainability agenda and the allocation of internal resources to achieve them. Figure 5 provides an overview of our data structure.

We named the first cluster (Cluster 1) of three firms operating in Quadrant I countries (Argentina, Mongolia, and Venezuela) the "defensive approach" in reference to the firms exerting minimal environmental efforts. It is plausible that their concerns for environmental management are the direct result of the legal requirements in host countries. An unfriendly investment climate deters them from investing much in environmental issues. They spend minimal effort on environmental protection and take action only when it is essential for their business survival [151], as stipulated by the laws and regulations passed by the local government.

"Accomplishing the regulatory target is our current target. The environmental standards here are undemanding. However, the Mongolian government's ambivalent attitude to FDI impedes our environmental proactivity [ ... ]. Shenhua Group (a Chinese state-owned mining and energy company) suffered a great loss in Tavan Tolgoi mining project and warn us it is better to avoid large resource commitment." (Firm B, Mongolia)

"The bad investment atmosphere in Venezuela increase much extra compliance cost. It is not bad to comply with the environmental regulatory requirements. We are much better than many local companies and even some western MNE subsidiaries. We want to be more proactive in local environmental protection, even if we do it well (environmental protection), Venezuelan government will not bring us any more favorable conditions in our subsequent investment projects. Now our priority is meeting the regulatory demand." (Firm C, Venezuela) 


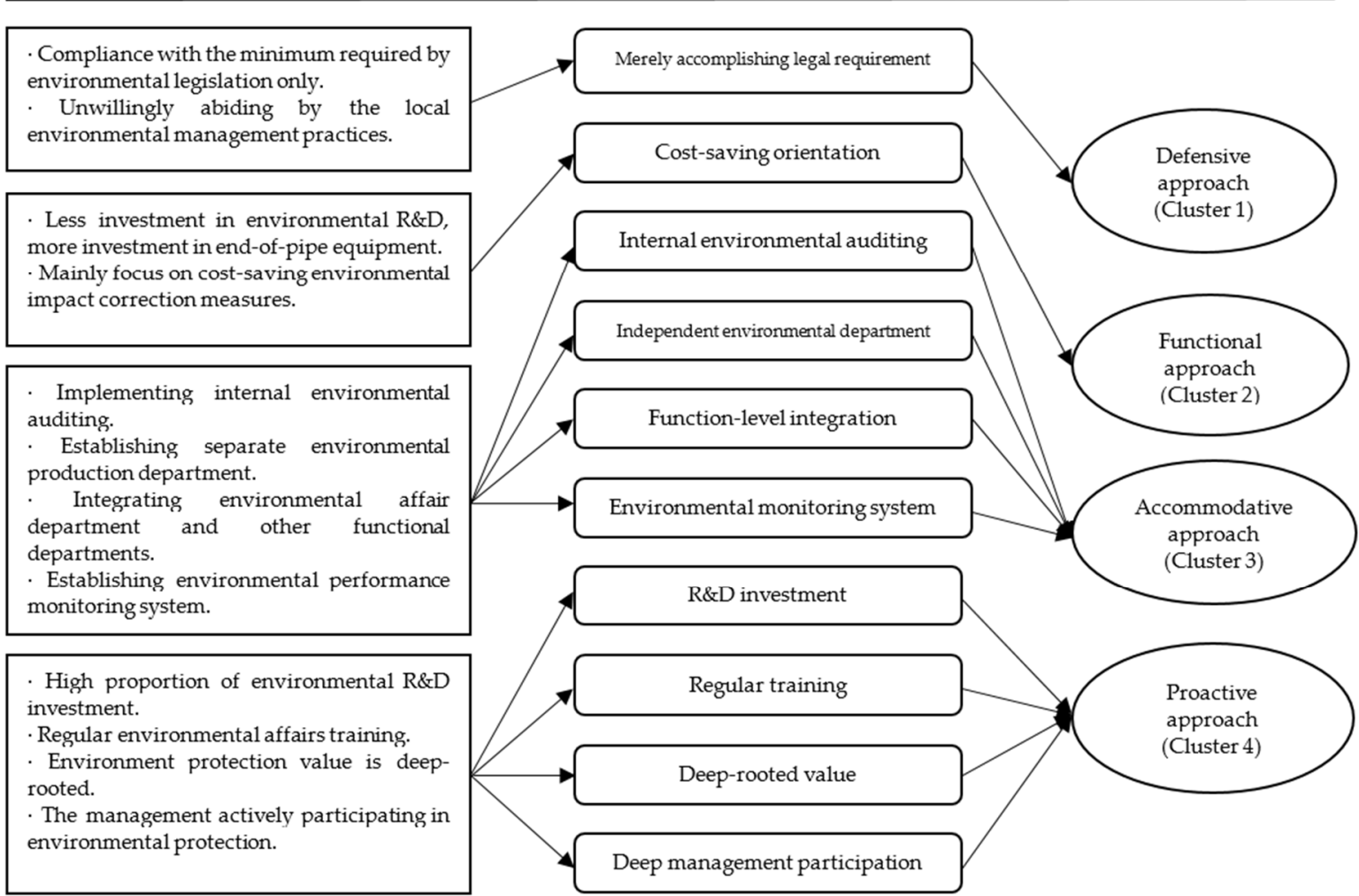

Figure 5. Four types of green governance response patterns.

We named the second cluster (Cluster 2) of three firms operating in Quadrant II countries (Nigeria, Peru, and Thailand) the "functional approach"; firms in this cluster exhibit utilitarianism in their approach to implementing pollution prevention practices. They exploit generous foreign investment incentives and lenient environmental regulation provided by local governments to enhance their cost advantage. They prefer cost-saving abatement measures, such as recycling and waste management, rather than investing heavily in environmentally benign technologies and management systems.

"Environmental protection should emphasize pragmatism. In this respect, cost saving is at the value center. Investment in environmental $R \& D$ is costly, time-consuming and with slow effect. [ ... ] Nigeria is a critical hub in our global strategic layout. We use many environmental protection measures, for example, waste treatment, recycling, and waste management. In the future, we are willing to adopt more proactive measures to protect local natural environment and promote the progress of local environment protection level." (Firm D, Nigeria)

"Thailand is a very important market and ASEAN center. Although the local environmental standards are lower than that in China, we take environment protection measures beyond its legal requirement. We introduced advanced equipment to take control of pollutant and help our company to save money." (Firm F, Thailand)

We named the third cluster (Cluster 3) of two firms operating in Quadrant III countries (Brazil and Kenya) the "accommodative approach". The firms in this cluster place a relatively high emphasis on internal environmental management, but are less focused on incorporating environmental issues into $R \& D$ and organizational culture. Stringent environmental regulations force firms to meet multifaceted environmental standards, leading them not only to invest in end-of-pipe equipment, but also emphasize an environmental protection system and mechanism construction. However, hostile local market conditions toward foreign investors hamper their massive commitment to environmental protection. 
"Brazilian government has strict environmental monitoring system, and its enforcement is very strict too. In order to improve our internal environmental management, we have strengthened internal environmental auditing and environmental monitoring system. Our purpose is preventing environmental events in any time and at any place. Considering the relatively restrictive investment and unfriendly operation environment, it is inappropriate to invest substantially in local environment protection." (Firm G, Brazil)

"Kenya is very enthusiastic about environmental protection. We need to establish separate environmental department and recruit professionals to respond to environmental affairs. We also have established function-level integration mechanism, and our environmental department often cooperate with other departments of our company and head environmental programs. Although Kenya is steadily improving investment environment for FDI, its FDI policy is still far behind many advanced economies. We can't get many environmental subsidies even if we do very well in environment protection, and it is unnecessary to invest a lot in this issues." (Firm H, Kenya)

We named the fourth cluster (Cluster 4) of three firms operating in Quadrant IV countries (Australia, Canada, and the United Kingdom) the "proactive approach", referring to firms placing a strong emphasis on local environment protection. Compared with the other three clusters, the green governance pattern of the proactive approach is well rounded and involves deep-rooted values incorporated into corporate values and the organization's strategic planning process and decisions. Attractive foreign investment policies spur the firms' investment, and strict environmental regulations make them emphasize long-term and sustainable corporate development. Therefore, they implement environmental protection as a daily business routine by building an environmental management system that clearly assigns environmental responsibilities and provides regular environmental training for employees.

"Environmental protection in Australia is a systematic task and should be rooted into our organizational culture. We have regular and frequent trainings on environmental issues, for example, handling of chemicals, soil restoration, waste management, and so on. Every year, we invested a lot in environmental protection and need to bear a large proportion of financial guarantee for aftercare. Australia is generally welcoming foreign investors, and there are few limits or restrictions on foreign investment in Australia. It is an ideal investment destination for us and we have a long-term commitment here." (Firm I, Australia)

"We take advanced industrial leading companies' environmental practice as our benchmark. We have invested a lot in environmental protection, for example, we have advanced equipment, systematic environmental affair training program, environmental related incentive and punitive mechanism. The concepts and consciousness of environmental protection have deeply rooted in our value and embodied in our practice. We believe that in environmental management, the more we devote, the more we get." (Firm J, Canada)

Through interviews, media coverage, and searching the sample firms' environmental criminal records in the respective countries, we found that apart from individual companies having petty environmental offenses, most sample firms obeyed the environmental regulations of their host countries. However, because of the differences in regulatory pressures and FDI attractiveness, they had different response patterns in different green governance contexts. Our findings reveal that both strict environmental regulation and friendly FDI policy can positively influence MNEs to adopt more active response patterns. Greater availability of environmental capabilities and technological capabilities does not affect the sample firms' environmental commitment. According to our findings, four types of green governance response patterns emerge and are validated in different green governance contexts, as shown in Figure 6. 


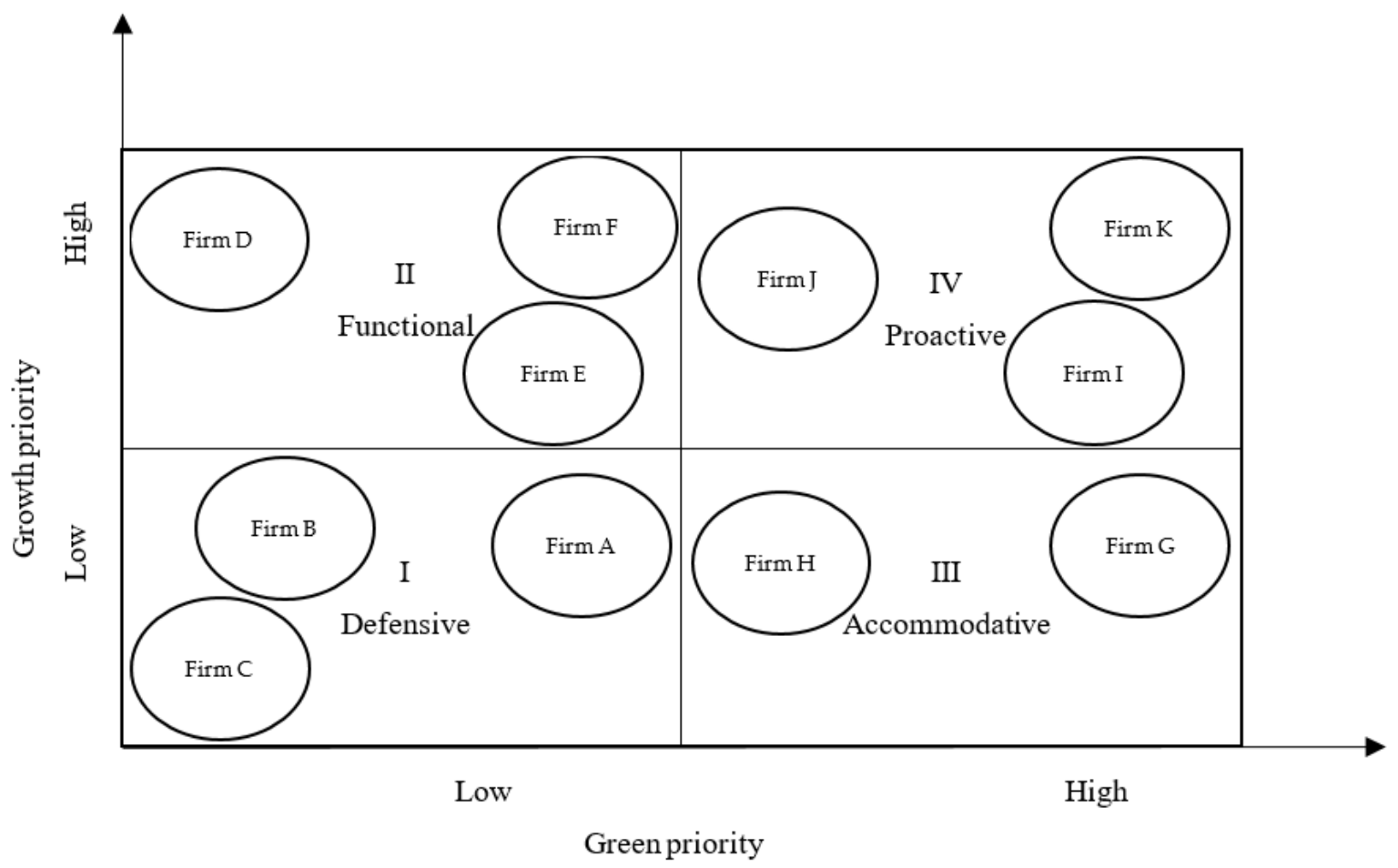

Figure 6. Chinese MNEs' strategic fit in green governance contexts.

Local governments of Quadrant II countries (Thailand, Nigeria, Peru) are more concerned with the short-term economic benefits of foreign investment, and EMNEs often respond adaptively by introducing utilitarian and cost-saving methods instead of best practices. The implementation of cost-reduction pollution prevention would entail immediate financial benefits from the "low-hanging fruit" of environmental practices [152]. On the contrary, in Quadrant IV countries (the UK, Australia, Canada), environmental issues are highly regulated and of concern to many. Thus, the most up-to-date environmental technological applications and regular training for employees would impart legitimacy to firms to facilitate their operation in these countries.

Although firms in Quadrant II countries could be more relaxed on environmental requirements, adopting a more active approach to pollution prevention could still attain benefits, such as reduced costs, an improved image, and the consequent related advantages over their counterparts. Moreover, a high level of growth priority and FDI incentives are appealing to foreign investors. They especially emphasize and are more willing to implement active environmental practices in these countries. In contrast to Quadrant I countries (Argentina, Mongolia, Venezuela), they have more incentives to exploit the lax environmental regulations to offset the increased cost caused by the host's hostile environment. Therefore, they often respond adaptively with minimal environmental efforts in these countries. Thus, we present Proposition 2a and Proposition 2b.

Proposition 2a. EMNEs are more likely to deploy more active green governance response patterns when the host countries impose a higher level of green priority.

Proposition $\mathbf{2 b}$. EMNEs are more likely to deploy more active green governance response patterns when the host countries impose a higher level of growth priority. 


\section{Discussion}

\subsection{Firm-Specific Capabilities Influence Emnes' Location Choice}

With the international investment flows increasing, environmental regulations have emerged as important determinants of corporate investment, and traditional barriers to trade have been dismantled $[10,96]$. Different environmental standards embody different entry requirements and lead to different competitive intensities. Competitive intensity is one of the most important factors of decision making in firms' choice of foreign location [153,154]. It is a function of the number of competitors in the market and the potential opportunities for future growth [155]. In countries with strict environmental regulations, the rigorous environmental standards have induced a high barrier to entry, which has helped filter out firms that are not up to scratch while vying with fewer competitors in the country: these factors allow the remaining firms to seize a large share of the profits. On the contrary, in countries with lax regulatory standards, EMNEs may confront more competitors, many of which are local artisanal and small-scale companies. This leads to direct conflict and competition for natural resources and market access [156]. Due to undeveloped environmental monitoring and enforcement, these companies enjoy a very low compliance cost and are deeply rooted in local communities [6]. For EMNEs, it is costly to conflict with these companies and communities [157]. Strong environmental capabilities help EMNEs distance themselves from the stereotypes of their home countries in an attempt to overcome their liability of origin, thereby removing barriers to legitimation in environmentally sensitive countries [90]. Firms that possess low environmental capabilities are more likely to face heightened barriers to entry, lag in international deployment, and encounter more intense competition.

It has been argued that economic growth is equivalent to a higher average income [158] and thus a higher average consumer budget [159], which leads to diverse market needs and picky consumers $[149,150]$. Thus, EMNEs need strong technological capabilities to move beyond organizational limits and develop new products and novel solutions to better satisfy market needs [160]. Strong technological capability can enable firms to adapt their operations to new operating conditions, accelerate new product development, and create open innovation to dismantle knowledge boundaries and break organizational growth limits $[28,32,102,161]$. Moreover, strong technological capabilities coupled with a robust product design process lead to fast product development and new high-quality products [160,162], which propel firms ahead of competitors [163]. By reaching customers in countries that prioritize economic growth, EMNEs are more likely to earn acceptable returns on invested capital and align their technological capabilities with host countries' growth opportunities. Our findings also reveal that technological capabilities can help EMNEs become more competitive and better grasp the host countries' growth opportunities.

\subsection{Green Governance Contexts Determine Emnes' Response Patterns}

FDI policies and environmental regulations can differ across countries, thereby allowing EMNEs to mobilize in response to opportunities and threats in different green governance contexts. On the basis of our findings, we propose that context-specific factors influence firms' green governance response patterns in two aspects.

First, regulatory pressure clearly influences the implementation of environmental responses and practices $[86,128]$. Companies doing business in advanced economies and environmentally sensitive countries may face strict regulations on environmental responsibility and stewardship of natural resources [164]. Therefore, adopting more active green governance response patterns can be considered as a means of survival in the host countries which impose a higher level of green priority.

Second, it is argued that the active adoption of green governance response patterns could enable firms to influence consumers in order to obtain higher prices for their products; lower the costs of labor, capital, and environmental regulations; and gain access to government assistance and payments $[165,166]$. Thus, implementing active green governance response patterns can realize general long-term business benefits for firms $[167,168]$. If company managers believe that there is a strong 
potential business opportunity for environmental management, they will be more inclined to comply with strict environmental regulations and integrate environmental practices into the design and operations of their businesses in the long run [169].

\subsection{Theoretical Model}

On the basis of the results and discussions, we propose the following theorized conceptual model (Figure 7) to help us understand the alignment between MNEs' IB strategies, green governance, and firm-specific capabilities. The left part of the model is the green governance context. We argue that different green governance contexts are caused by different policy preferences for green priority and growth priority. The formation of green governance policy is a complex process and can be analyzed by the DPSIR framework. The Drivers-Pressure-State-Impact-Response (DPSIR) framework is a functional analysis scheme for structuring the cause-effect relationships at macro-levels, such as nations and regions [170]. It is the prelude to the formulation of green policy and growth policy, and eventually creating different green governance contexts. The right part of the model is MNE's global sustainability development capability portfolio. We propose that both the external green governance context and an internal MNE's capability portfolio will influence an MNE's IB strategies. Looking through the framework, it is argued, will enable scholars, managers, and policy makers to connect macro national green governance policies to micro firm specific capabilities, and will be of use for future scientific enquiry and policy analysis.

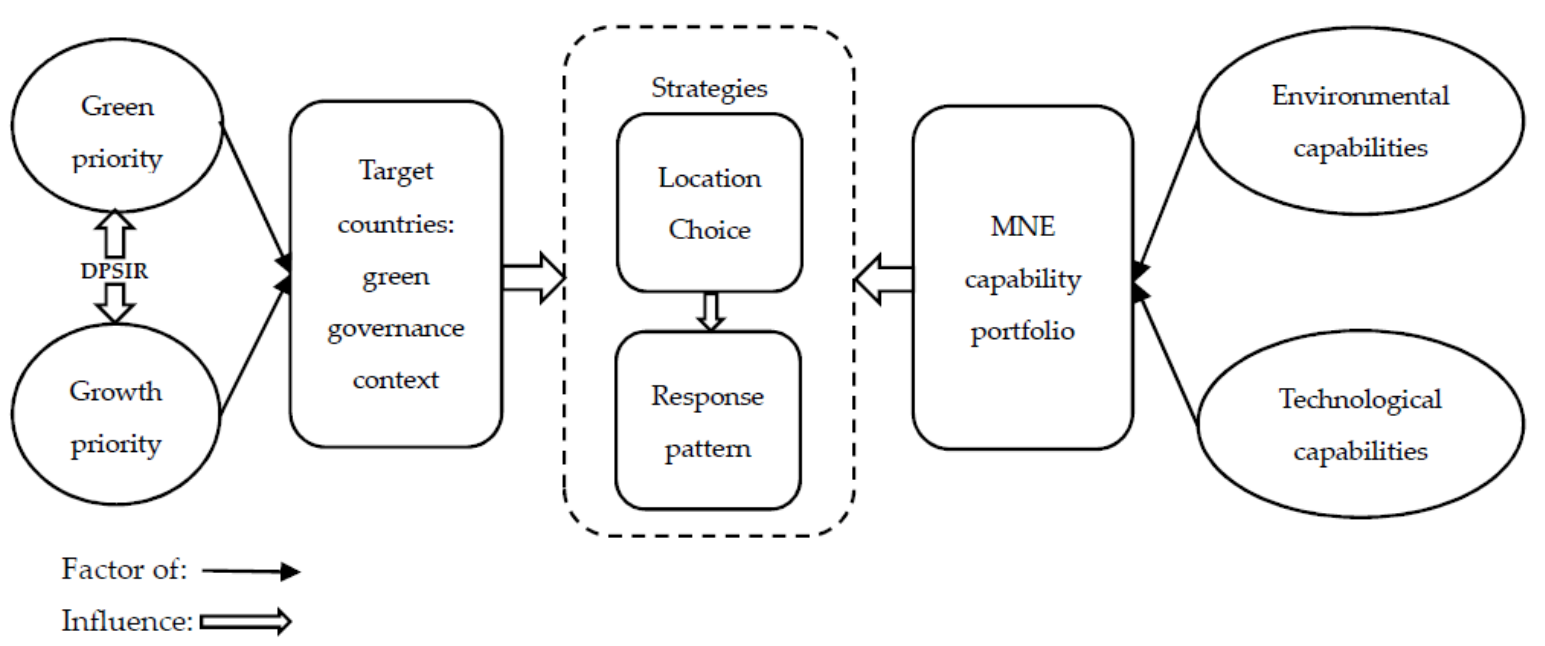

Figure 7. Strategic fit model of IB strategies between green governance context of target countries and an MNE's global sustainability development capability portfolio.

\section{Conclusions}

\subsection{Summary and Implications}

Successful IB strategies rely on the alignment between the organizational capabilities and the global business environment. However, there is still scant research on how firms' IB strategies are shaped by internal firms' specific capabilities and external governmental green governance policies, partly because of the simple dichotomous typology of the green governance context, and partly because of the challenge in obtaining effective information about strategists' decision-making processes and firms' environmental practices.

Governmental green governance, by its nature, is dynamic. Through decades of continuous efforts toward environmental protection, many countries that are formerly known as developing, poor, or southern have made significant progress in environmental protection legislation and enforcement $[47,48]$. In addition, many governments have increasingly come to see FDI as an important driver of economic growth [10]. This paper contributes to the green governance literature by extending 
the green governance context typology, with a particular focus on EMNEs' IB strategies in different green governance contexts. Specifically, we argue that it is time to move beyond a simple dichotomy that divides the world into developed and developing, rich and poor, or north and south countries. There is a need to consider more fine-grained notions of green governance contexts with varying degrees of FDI attractiveness and environmental regulatory stringency. These differences contribute to a reinvigoration and extension of IB strategies related to green governance.

Through a strategic fit perspective and resource-based view, this study investigates interfirm differences in investment location decisions and classifies different response patterns. In this paper, we argue that because EMNEs are heterogeneous in their environmental capabilities and technological capabilities, they are also heterogeneous in their preferences for and responses to green governance contexts. As a result, EMNEs develop distinct IB strategies. According to the results obtained from a sample of 11 Chinese pollution-intensive MNEs, we find that: (1) the green governance context is a significant factor in MNEs' global location choice and is an important driving force behinds MNEs' response patterns; (2) environmental capabilities enable MNEs to pass through a host country's environmental entry barrier and facilitate a wider global business deployment; (3) technological capabilities help MNEs become more competitive and better harness the host countries' growth opportunities; (4) four types of green governance response patterns are proposed and validated; and (5) both strict environmental regulation and friendly FDI policy can positively influence MNEs to adopt more active response patterns, and greater availability of environmental capabilities and technological capabilities does not affect MNEs' environmental commitment. These findings suggest that in order to succeed in different green governance contexts, EMNEs seem to seek alignment between internal capabilities and external green governance context.

Finally, this study highlights several implications for managers and policymakers. First of all, it is essential for MNEs to pay more attention to developing their environmental capabilities, as firms lacking environmental capabilities are more likely to face heightened barriers to entry and public scrutiny and are more likely to lag in international deployment. Second, the findings highlight the need for technological capabilities to enhance EMNEs' competitive advantage. Most EMNEs have a deficit in technological capabilities. It is argued that open innovation can be an effective means to dismantle the knowledge boundary and enhance an organization's technological strength $[32,161]$. Third, in addition to the firm's role, we highlight the decisive role played by government agencies. Government agencies should be involved and encouraged to provide incentives and financial support to firms deploying active environmental approaches that benefit local environmental protection.

\subsection{Contributions}

This study makes three primary contributions.

First, this study delineates a more fine-grained notion of the green governance context with varying degrees of FDI attraction and environmental protection. Related previous research has largely centered on a simple dichotomy that divides the world into developed and developing, rich and poor, or north and south. This type of superficial classification limits our understanding of diverse green governance contexts. These differences contribute to a reinvigoration and extension of IB strategies related to green governance.

Second, the study extends our understanding of the heterogeneous EMNEs' IB strategies that are shaped by external green governance contexts and internal firm-specific capabilities. Previous research has explored the effects of FDI policy and environmental regulation on firms' IB strategies individually. However, the previous research has rarely considered the two effects on EMNEs' IB strategies simultaneously. In practice, when firms expand abroad, they encounter a unique combination of national policies that define the "rules of the game" for doing business in that particular country [171]. Moreover, previous research has not investigated firms' specific capabilities that can be developed and deployed to enable these organizations to proactively prepare to harness the opportunities and mitigate the threats. Therefore, we contributed to the previous research on the 
international strategy-capability-environment alignment of EMNEs in a fine-grained typology of the green governance context.

Third, this study empirically develops an exploratory taxonomy of green governance response patterns that capture the major responsive engagement among EMNEs. It is helpful for IB scholars to further their understanding of the conceptual schemes of green governance underpinning localization and legitimization practices in host countries. The taxonomy of green governance contexts and firms' response patterns also contribute as a roadmap for business decision makers to choose the appropriate IB strategies in global markets.

\subsection{Limitations and Future Research}

This study also has limitations which present avenues for future research. First, our interviews focused on the managers of the sample firms, but each manager provided the environmental practices and performances in different breadths and details to best serve their own stakeholders. Although we have made some efforts, including the design of our interview, to correct this bias, the evaluation might not completely reflect the firm's actual environmental performance and capabilities. Future studies could extend the pool of interviewees to local environmental departments and NGOs to depict the sample firms through multiple channels of information. Second, employing multiple case studies does not effectively test the linkages between governmental green governance policies and EMNEs' IB strategies or the linkages between firm-specific capabilities and EMNEs' IB strategies. Future research is needed to explore the generalizability of our findings. It is suggested that research focuses on MNEs from other emerging economies, preferably using a cross-sectional survey data set or longitudinal approach to gather more evidence to confirm or refine our findings. Third, this study focuses on the governmental force placed on firms' IB strategies. However, green governance mechanisms involve many players, such as governments, firms, social organizations, and the public [1,21]. Scherer and Palazzo noted a governance shift from a governmental force (formal rules and sanctions) to a civil force (voluntary self-regulation) [172]. This new "civil governance" infrastructure is characterized by non-legal forms of regulation at an international level [173]. Future studies may concentrate more on the effects of non-state forces, such as the public, media, and NGOs, on MNEs' IB strategies. Fourth, this study focuses on natural environmental issues, which is one aspect of green governance and sustainability. Green governance is a very broad concept that includes long-term economic, social, and environmental sustainability [1]. Future research could extend green governance research to a broader perspective. For example, most of our sample firms are mining companies. In the mining sector, financial guarantees are a popular practice for ensuring environmental reclamation and employee aftercare after the mine's closure. The financial guarantee mechanism involves both environmental sustainability and social sustainability. Future studies could widen the scope for a broader view and focus more on multifunctional mechanisms In sum, this study takes an initial and exploratory step toward the international strategy-capability-environment alignment of EMNEs in different green governance contexts. Further studies are necessary to examine and refine the validity of our findings.

Author Contributions: R.L. conceived of the idea of the paper and designed the research; Y.G. wrote the paper and participated in all phases; Z.X. and L.L. reviewed related previous literature and provided constructive suggestions to improve the research. All authors have read and approved the final manuscript.

Funding: This paper was supported by the National Natural Science Foundation of China (Grant No. 71533002, 71772096, 71602139, 71702128); Major Projects of the Key Research Base of Humanities and Social Sciences of the Ministry of Education, China (Grant No. 16JJD630002); and the Research Project of Ministry of Education, Humanities and Social Sciences project, China (Grant No. 18YJC630233).

Acknowledgments: The authors especially thank the editors and anonymous reviewers for their kind review and helpful comments. We highly appreciate one of our anonymous reviewers for pointing out financial guarantee mechanism.

Conflicts of Interest: The authors declare no conflict of interest. 


\section{References}

1. Li, W.; Xu, J.; Zheng, M. Green governance: New perspective from open innovation. Sustainability 2018, 10, 3845. [CrossRef]

2. Lim, H.; Eun, J. Exploring Perceptions of Sustainable Development in South Korea: An Approach Based on Advocacy Coalition Framework's Belief System. J. Open Innov. Technol. Mark. Complex. 2018, 4, 54. [CrossRef]

3. Van Zeijl-Rozema, A.; Cörvers, R.; Kemp, R.; Martens, P. Governance for sustainable development: A framework. Sustain. Dev. 2008, 16, 410-421. [CrossRef]

4. De Mello, L. Foreign direct investment-led growth: Evidence from time series and panel data. Oxf. Econ. Pap. 1999, 51, 133-151. [CrossRef]

5. Markusen, J.R.; Venables, A.J. Foreign direct investment as a catalyst for industrial development. Eur. Econ. Rev. 1999, 43, 335-356. [CrossRef]

6. Shapiro, D.; Hobdari, B.; Oh, C.H. Natural resources, multinational enterprises and sustainable development. J. World Bus. 2018, 53, 1-14. [CrossRef]

7. Mabey, N.; McNally, R. Foreign Direct Investment and the Environment: From Pollution Havens to Sustainable Development; OECD: Paris, France, 1999.

8. Peng, M.W.; Sun, S.L.; Pinkham, B.; Chen, H. The institution-based view as a third leg for a strategy tripod. Acad. Manag. Perspect. 2009, 23, 63-81. [CrossRef]

9. Peng, M.W.; Wang, D.Y.; Jiang, Y. An institution-based view of international strategy: A focus on emerging markets. J. Int. Bus. Stud. 2008, 39, 920-936. [CrossRef]

10. Madsen, P.M. Does Corporate Investment Drive A Race to the Bottom in Environmental Protection? A Reexamination of the Effect of Environmental Regulation on Investment. Acad. Manag. J. 2009, 52, 1297-1318. [CrossRef]

11. Etzion, D. Research on organizations and the natural environment, 1992-present: A review. J. Manag. 2007, 33, 637-664. [CrossRef]

12. Song, S. Unfavorable Market Conditions, Institutional and Financial Development, and Exits of Foreign Subsidiaries. J. Int. Manag. 2014, 20, 279-289. [CrossRef]

13. EPI. 2016 Environmental Performance Index Report; Yale University: New Haven, CT, USA; Columbia University: New York, NY, USA, 2016.

14. UNCTAD. World Investment Report 2015: Reforming International Investment Governance; UNCTAD: Geneva, Switzerland, 2015.

15. EPI. 2018 Environmental Performance Index; Yale University: New Haven, CT, USA; Columbia University: New York, NY, USA, 2018.

16. UNCTAD. World Investment Report 2010: Investing in a Low-carbon Economy; UNCTAD: Geneva, Switzerland, 2010.

17. UNCTAD. World Investment Report 2016: Investor Nationality: Policy Challenges; UNCTAD: Geneva, Switzerland, 2016.

18. North, D. Institutions, Institutional Change, and Economic Performance; Cambridge University Press: Cambridge, UK, 1990.

19. Hoskisson, R.; Eden, L.; Lau, C.; Wright, M. Strategy in emerging economies. Acad. Manag. J. 2000, 43, 249-267.

20. Wright, M.; Filatochev, I.; Hoskisson, R.; Peng, M. Strategy research in emerging economies: Challenging the conventional wisdom. J. Manag. Stud. 2005, 42, 1-33. [CrossRef]

21. Cooke, P. Green governance and green clusters: Regional \& national policies for the climate change challenge of Central \& Eastern Europe. J. Open Innov. Technol. Mark. Complex. 2015, 1, 1-17.

22. Venkatraman, N.; Camillus, J.C. Exploring the concept of "fit" in strategic management. Acad. Manag. Rev. 1984, 9, 513-525.

23. Madhok, A.; Keyhani, M. Acquisitions as entrepreneurship: Asymmetries, opportunities, and the internationalization of multinationals from emerging economies. Glob. Strateg. J. 2012, 2, 26-40. [CrossRef]

24. Pant, A.; Ramachandran, J. Legitimacy beyond borders: Indian software services firms in the United States, 1984 to 2004. Glob. Strateg. J. 2012, 2, 224-243. [CrossRef]

25. Peng, M.W. The global strategy of emerging multinationals from China. Glob. Strateg. J. 2012, 2, 97-107. [CrossRef] 
26. Frost, S.; Ho, M. 'Going Out': The Growth of Chinese Foreign Direct Investment in Southeast Asia and Its Implications for Corporate Social Responsibility. Corp. Soc. Responsib. Environ. Manag. 2005, 12, 157-167. [CrossRef]

27. Zyglidopoulos, S.; Williamson, P.; Symeou, P.C. The corporate social performance of developing country multinationals. Bus. Ethics Q. 2016, 26, 379-406. [CrossRef]

28. Pek, S.; Oh, C.H.; Rivera, J. MNC foreign investment and industrial disasters: The moderating role of technological, safety management, and philanthropic capabilities. Strat. Manag. J. 2018, 39, 502-526. [CrossRef]

29. Wang, K.; Zhang, H.; Tsai, S.-B.; Wu, L.; Xue, K.; Fan, H.; Zhou, J.; Chen, Q. Does a Board Chairman's Political Connection Affect Green Investment?-From a Sustainable Perspective. Sustainability 2018, 10, 582. [CrossRef]

30. Li, H.; Zhang, H.; Tsai, S.-B.; Qiu, A. China's insurance regulatory reform, corporate governance behavior and insurers' governance effectiveness. Int. J. Environ. Res. Public Health 2017, 14, 1238. [CrossRef] [PubMed]

31. Yun, J.H.J. How do we conquer the growth limits of capitalism? Schumpeterian dynamics of open innovation. J. Open Innov. Technol. Mark. Complex. 2015, 17, 1-26. [CrossRef]

32. Yun, J.H.J.; Won, D.K.; Park, K.B. Entrepreneurial cyclical dynamics of open innovation. J. Evol. Econ. 2018, 28, 1151-1174. [CrossRef]

33. Lee, S.-D. Wintering Habitat use pattern of red-crowned cranes in the Korean Demilitarized Zone. J. Open Innov. Technol. Mark. Complex. 2018, 4, 58. [CrossRef]

34. Gao, Y.; Tsai, S.-B.; Xue, X.; Ren, T.; Du, X.; Chen, Q.; Wang, J. An empirical study on green innovation efficiency in the green institutional environment. Sustainability 2018, 10, 724. [CrossRef]

35. Wang, X.; Sun, C.; Wang, S.; Zhang, Z.; Zou, W. Going Green or going away? A spatial empirical examination of the relationship between environmental regulations, biased technological progress, and green total factor productivity. Int. J. Environ. Res. Public Health 2018, 15, 1917. [CrossRef]

36. World Bank. Governance and Development; World Bank: Washington, DC, USA, 1992.

37. Zhu, S.J.; He, C.F.; Liu, Y. Going green or going away: Environmental regulation, economic geography and firms' strategies in China's pollution-intensive industries. Geoforum 2014, 55, 53-65. [CrossRef]

38. World Bank. Inclusive Green Growth: The Pathway to Sustainable Development; World Bank: Washington, DC, USA, 2012.

39. Huh, T.; Kim, Y.; Kim, J.H. Towards a green state: A comparative study on OECD countries through fuzzy-set analysis. Sustainability 2018, 10, 3181. [CrossRef]

40. Chowdhury, A.; Mavrotas, G. FDI and growth: What causes what? World Econ. 2006, 29, 9-19. [CrossRef]

41. Harris, P.G. Sharing the burdens of environmental change: Comparing EU and U.S. policies. J. Environ. Dev. 2002, 11, 380-401. [CrossRef]

42. Vogel, D. The hare and the tortoise revisited: The new politics of consumer and environmental protection in Europe. Br. J. Polit. Sci. 2003, 33, 557-580. [CrossRef]

43. Desombre, E.R. Global Environmental Governance for a New Green Economy. Rev. Policy Res. 2011, 28, 467-472. [CrossRef]

44. Bradley, T.; Ziniel, C. Green governance? Local politics and ethical businesses in Great Britain. Bus. Ethics 2017, 26, 18-30. [CrossRef]

45. Dinda, S. Environmental Kuznets Curve hypothesis: A survey. Ecol. Econ. 2004, 49, 431-455. [CrossRef]

46. Gugler, P.; Shi, J.Y. Corporate social responsibility for developing country multinational corporations: Lost war in pertaining global competitiveness? J. Bus. Ethics 2009, 87, 3-24. [CrossRef]

47. Mol, A. China's assent and Africa's environment. Glob. Environ. Chang. 2011, 21, 785-794. [CrossRef]

48. Azadegan, A.; Golara, S.; Kach, A.; Mousavi, N. Corporate environmental investments: A cross-national study on managerial decision making. Int. J. Prod. Econ. 2018, 199, 47-64. [CrossRef]

49. Rock, M.; Murphy, J.T.; Rasiah, R.; van Seters, P.; Managi, S. A hard slog, not a leap frog: Globalization and sustainability transitions in developing Asia. Technol. Forecast. Soc. Chang. 2009, 76, 241-254. [CrossRef]

50. Everitt, B.S.; Dunn, G. Applied Multivariate Data Analysis, 2nd ed.; Wiley: New York, NY, USA, 1991.

51. Baron, D.P. The nonmarket strategy system. Sloan Manag. Rev. 1995, 37, 73-85.

52. Weidenbaum, M.L. Public policy: No longer a spectator sport for business. J. Bus. Strateg. 1980, 1, 46-53. [CrossRef] 
53. Holmes, R.M., Jr.; Miller, T.; Hitt, M.A.; Salmador, M.P. The interrelationships among informal institutions, formal institutions, and inward foreign direct investment. J. Manag. 2013, 39, 531-566. [CrossRef]

54. Brainard, S.L. An Empirical Assessment of the Proximity-Concentration Trade-off between Multinational Sales and Trade. Am. Econ. Rev. 1997, 87, 520-544.

55. Davies, R.B. State Tax Competition for Foreign Direct Investment: A Winnable War? J. Int. Econ. 2005, 67, 498-512. [CrossRef]

56. Boddewyn, J.J. Political aspects of MNE theory. J. Int. Bus. Stud. 1988, 19, 341-363. [CrossRef]

57. Hennart, J.F. Can the new forms of investment substitute for the old forms: A transaction costs perspective. J. Int. Bus. Stud. 1989, 20, 211-234. [CrossRef]

58. Hillman, A.J.; Hitt, M.A. Corporate political strategy formulation: A model of approach, participation, and strategy decisions. Acad. Manag. Rev. 1999, 24, 825-842. [CrossRef]

59. Lee, S.H.; Song, S. Host country uncertainty, intra-MNC production shifts, and subsidiary performance. Strat. Manag. J. 2012, 33, 1331-1340. [CrossRef]

60. Fisch, J.H.; Zschoche, M. The effect of operational flexibility on decisions to withdraw from foreign production locations. Int. Bus. Rev. 2012, 21, 806-815. [CrossRef]

61. Belderbos, R.; Zou, J. Real options and foreign affiliate divestments: A portfolio perspective. J. Int. Bus. Stud. 2009, 40, 600-620. [CrossRef]

62. Fisch, J.H.; Zschoche, M. Do firms benefit from multinationality through production shifting? J. Int. Manag. 2011, 17, 143-149. [CrossRef]

63. Kogut, B.; Kulatilaka, N. Operating flexibility, global manufacturing, and the option value of a multinational network. Manag. Sci. 1994, 40, 123-139. [CrossRef]

64. Buckley, P.J.; Casson, M.C. Analyzing foreign market entry strategies: Extending the internalization approach. J. Int. Bus. Stud. 1998, 29, 539-562. [CrossRef]

65. Miller, K.D. A framework for integrated risk management in international business. J. Int. Bus. Stud. 1992, 23, 311-331. [CrossRef]

66. Delios, A.; Beamish, P.W. Ownership strategy of Japanese firms: Transactional, institutional, and experience influences. Strat. Manag. J. 1999, 20, 915-933. [CrossRef]

67. Banerjee, S.B. Managerial implications of corporate environmentalism: Interpretations from industry and strategic implications for organizations. J. Manag. Stud. 2001, 38, 489-513. [CrossRef]

68. Fineman, S.; Clarke, K. Green stakeholders: Industry interpretations and response. J. Manag. Stud. 1996, 33, 715-730. [CrossRef]

69. Jeppesen, T.; List, J.A.; Folmer, H. Environmental regulations and new plant location decisions: Evidence from a meta-analysis. J. Reg. Sci. 2002, 42, 19-49. [CrossRef]

70. Testa, F.; Iraldo, F.; Frey, M. The effect of environmental regulation on firms' competitive performance: The case of the building \& construction sector in some EU regions. J. Environ. Manag. 2011, 92, 2136-2144.

71. Cave, L.A.; Blomquist, G.C. Environmental policy in the European Union: Fostering the development of pollution havens? Ecol. Econ. 2008, 65, 253-261. [CrossRef]

72. Delmas, M.; Toffel, M.W. Organizational responses to environmental demands: Opening the black box. Strateg. Manag. J. 2008, 29, 1027-1055. [CrossRef]

73. Costantini, V.; Crespi, F. Environmental regulation and the export dynamics of energy technologies. Ecol. Econ. 2008, 66, 447-460. [CrossRef]

74. Mulatu, A.; Gerlagh, R.; Rigby, D.; Wossink, A. Environmental regulation and industry location in Europe. Environ. Resour. Econ. 2010, 45, 459-479. [CrossRef]

75. Cerdeira Bento, J.P.; Moreira, A. Environmental impact of FDI-the case of US subsidiaries. Multinatl. Bus. Rev. 2018. Available online: https:/ /www.emeraldinsight.com/doi/pdfplus/10.1108/MBR06-2017-0038 (accessed on 6 February 2019). [CrossRef]

76. Porter, M.E. Towards a dynamic theory of strategy. Strat. Manag. J. 1991, 12, 95-117. [CrossRef]

77. Porter, M.E.; van der Linde, C. Toward a new conception of the environment competitiveness relationship. J. Econ. Perspect. 1995, 9, 97-118. [CrossRef]

78. Bernauer, T.; Caduff, L. In whose interest? Pressure group politics, economic competition and environmental regulation. J. Public Policy 2004, 24, 99-126. [CrossRef]

79. Chen, P.-H.; Ong, C.-F.; Hsu, S.-C. The linkages between internationalization and environmental strategies of multinational construction firms. J. Clean. Prod. 2016, 116, 207-216. [CrossRef] 
80. Murillo-Luna, J.L.; Garcés-Ayerbe, C.; Rivera-Torres, P. Why do patterns of environmental response differ? A stakeholders' pressure approach. Strat. Manag. J. 2008, 29, 1225-1240. [CrossRef]

81. Triebswetter, U.; Wackerbauer, J. Integrated environmental product innovation in the region of Munich and its impact on company competitiveness. J. Clean. Prod. 2008, 16, 1484-1493. [CrossRef]

82. Albertini, E. Does Environmental Management Improve Financial Performance? A Meta-Analytical Review. Organ. Environ. 2013, 26, 431-457. [CrossRef]

83. Schmidheiny, S. Changing Course: A Global Business Perspective on Development and the Environment; MIT Press: Cambridge, MA, USA, 1992.

84. Jiang, Y.; Xue, X.; Xue, W. Proactive Corporate Environmental Responsibility and Financial Performance: Evidence from Chinese Energy Enterprises. Sustainability 2018, 10, 964. [CrossRef]

85. Bansal, P.; Roth, K. Why companies go green: A model for ecological responsiveness. Acad. Manag. J. 2000, 43, 717-730.

86. Buysse, K.; Verbeke, A. Proactive environmental strategies: A stakeholder management perspective. Strat. Manag. J. 2003, 24, 453-470. [CrossRef]

87. Henriques, I.; Sadorsky, P. The determinant of an environmentally responsive firm: An empirical approach. J. Env. Econ. Manag. 1996, 30, 381-395. [CrossRef]

88. Sharma, S.; Henriques, I. Stakeholder influences on sustainability practices in the Canadian forest products industry. Strat. Manag. J. 2005, 26, 159-180. [CrossRef]

89. Winn, M.I.; Angell, L.C. Towards a process model of corporate greening. Organ. Stud. 2000, 6, 1119-1147. [CrossRef]

90. Marano, V.; Tashman, P.; Kostova, T. Escaping the iron cage: Liabilities of origin and CSR reporting of emerging market multinational enterprises. J. Int. Bus. Stud. 2017, 48, 386-408. [CrossRef]

91. Cuervo-Cazurra, A.; Ramamurti, R. Understanding Multinationals from Emerging Markets; Cambridge University Press: Cambridge, UK, 2014.

92. Doh, J.; Husted, B.W.; Yang, X. Guest Editors' Introduction: Ethics, Corporate Social Responsibility, and Developing Country Multinationals. Bus. Ethics Q. 2016, 26, 301-315. [CrossRef]

93. Preuss, L.; Barkemeyer, R.; Glavas, A. Corporate Social Responsibility in Developing Country Multinationals: Identifying Company and Country-Level Influences. Bus. Ethics Q. 2016, 26, 347-378. [CrossRef]

94. Barney, J.B. Firm resources and sustained competitive advantage. J. Manag. 1991, 17, 99-120. [CrossRef]

95. Hart, S.L. A natural-resource-based view of the firm. Acad. Manag. Rev. 1995, 20, 986-1014. [CrossRef]

96. Vogel, D. The Market for Virtue: The Potential and Limits of Corporate Social Responsibility; Brookings Institution Press: Washington, DC, USA, 2005.

97. Russo, M.V.; Fouts, P.A. A resource-based perspective on corporate environmental performance and profitability. Acad. Manag. J. 1997, 40, 534-559.

98. Shrivastava, P. Environmental technologies and competitive advantage. Strateg. Manag. J. 1995, 16, $183-200$. [CrossRef]

99. Aspelund, A. and Moen, Ø. Internationalization of small high-tech firms: The role of information technology. J. Eur. Mark. 2004, 13, 85-105. [CrossRef]

100. Glavas, C.; Mathews, S.; Bianchi, C. International opportunity recognition as a critical component for leveraging Internet capabilities and international market performance. J. Int. Entrep. 2017, 15, 1-35. [CrossRef]

101. Moorman, C.; Slotegraaf, R.J. The contingency value of complementary capabilities in product development. J. Mark. Res. 1999, 36, 239-257. [CrossRef]

102. Tsai, K.H. The impact of technological capability on firm performance in Taiwan's electronics industry. J. High Technol. Manag. 2004, 15, 183-195. [CrossRef]

103. Zahra, S.A.; Nielsen, A.P. Sources of capabilities, integration and technology commercialization. Strat. Manag. J. 2002, 23, 377-398. [CrossRef]

104. Franco, A.M.; Sarkar, M.B.; Agarwal, R.; Echambadi, R. Swift and smart: The moderating effects of technological capabilities on the market pioneering-firm survival relationship. Manag. Sci. 2009, 55, 1842-1860. [CrossRef]

105. Lei, H.-S.; Chen, Y.-S. The right tree for the right bird: Location choice decision of Taiwanese firms' FDI in China and Vietnam. Int. Bus. Rev. 2011, 20, 338-352. [CrossRef] 
106. Gippner, O.; Torney, D. Shifting policy priorities in EU-China energy relations: Implications for Chinese energy investments in Europe. Energy Policy 2017, 101, 649-658. [CrossRef]

107. Thomas, S. China's nuclear export drive: Trojan horse or Marshall plan? Energy Policy 2017, 101, $683-691$. [CrossRef]

108. Kumar, N. India's Global Powerhouses: How They Are Taking on the World; Harvard Business School Press: Boston, MA, USA, 2009.

109. Piperopoulos, P.; Wu, J.; Wang, C. Outward FDI, location choices and innovation performance of emerging market enterprises. Res. Policy 2018, 47, 232-240. [CrossRef]

110. Wu, J.; Park, S. The role of institutional complexity on emerging multinationals' innovation outcomes. Glob. Strateg. J. 2017. Available online: https://onlinelibrary.wiley.com/doi/abs/10.1002/gsj.1166 (accessed on 6 February 2019). [CrossRef]

111. Li, S.; Fetscherin, M.; Alon, I.; Lattemann, C.; Yeh, K. Corporate Social Responsibility in Emerging Markets: The Importance of the Governance Environment. Manag. Int. Rev. 2010, 50, 635-654. [CrossRef]

112. Li, S.; Filer, L. The effects of the governance environment on the choice of investment mode and the strategic implications. J. World Bus. 2007, 42, 80-98. [CrossRef]

113. Chung, C.H.; Lee, S.H.; Beamish, P.; Isobe, T. Subsidiary expansion/contraction during times of economic crisis. J. Int. Bus. Stud. 2010, 41, 500-525. [CrossRef]

114. Cuypers, I.R.P.; Martin, X. What makes and what does not make a real option? A study of international joint ventures. J. Int. Bus. Stud. 2010, 41, 47-69. [CrossRef]

115. Dai, L.; Eden, L.; Beamish, P.W. Place, space, and geographical exposure: Foreign subsidiary survival in conflict zones. J. Int. Bus. Stud. 2013, 44, 554-578. [CrossRef]

116. Erramilli, M.K.; D'Souza, D.E. Uncertainty and foreign direct investment: The role of moderators. Int. Mark. Rev. 1995, 12, 47-60. [CrossRef]

117. Miller, K.D.; Folta, T.B. Option value and entry timing. Strat. Manag. J. 2002, 23, 655-665. [CrossRef]

118. Doz, Y. Qualitative research for international business. J. Int. Bus. Stud. 2011, 42, 582-590. [CrossRef]

119. Yin, R.K. Case Study Research: Design and Methods, 3rd ed.; Sage Publications: London, UK, 2003.

120. Eisenhardt, K.M. Building theories from case study research. Acad. Manag. Rev. 1989, 14, 532-550. [CrossRef]

121. Mohr, L.B. Explaining Organizational Behavior; Jossey-Bass: San Francisco, CA, USA, 1982.

122. Markus, M.L.; Robey, D. Information Technology and Organizational Change: Causal Structure in Theory and Research. Manag. Sci. 1988, 34, 583-598. [CrossRef]

123. Du, J.; Zhang, Y. Does One Belt One Road initiative promote Chinese overseas direct investment? China Econ. Rev. 2018, 47, 189-205. [CrossRef]

124. Banerjee, S.B. Whose land is it anyway? National interest, indigenous stakeholders, and colonial discourses: The case of the Jabiluka uranium mine. Organ Environ. 2000, 13, 13-38. [CrossRef]

125. Warhurst, A.; Mitchell, P. Corporate social responsibility and the case of the summitville mine. Resour. Policy 2000, 26, 91-102. [CrossRef]

126. Warhurst, A. Corporate citizenship and corporate social investment: Drivers of tri-sector partnerships. J. Corp. Citizsh. 2001, 1, 57-73.

127. Kapelus, P. Mining, corporate social responsibility and the "Community": The case of Rio Tinto, Richards Bay Minerals and the Mbonambi. J. Bus. Ethics 2002, 39, 279-296. [CrossRef]

128. Henriques, I.; Sadorsky, P. The Relationship Between Environmental Commitment and Managerial Perceptions of Stakeholder Importance. Acad. Manag. J. 1999, 42, 87-99.

129. Mutti, D.; Yakovleva, N.; Vazquez-Brust, D.; Di Marco, M.H. Corporate social responsibility in the mining industry: Perspectives from stakeholder groups in Argentina. Resour. Policy 2012, 37, 212-222. [CrossRef]

130. Tan, J. Institutional Structure and Firm Social Performance in Transitional Economies: Evidence of Multinational Corporations in China. J. Bus. Ethics 2009, 86, 171-189. [CrossRef]

131. Tan, J.; Wang, L. MNC Strategic Responses to Ethical Pressure: An Institutional Logic Perspective. J. Bus. Ethics 2011, 98, 373-390. [CrossRef]

132. Buchanan, S.; Marques, J.C. How home country industry associations influence MNE international CSR practices: Evidence from the Canadian mining industry. J. World Bus. 2018, 53, 63-74. [CrossRef]

133. Narula, R. Multinational firms and the extractive sectors in the 21st century: Can they drive development? J. World Bus. 2018, 53, 85-91. [CrossRef] 
134. Manakkalathil, J.; Rudolf, E. Corporate social responsibility in a globalizing market. Adv. Manag. J. 1995, 60, $29-47$.

135. Fay, M.; Wang, J.; Draugelis, G.; Deichmann, U. Role of green governance in achieving sustainable urbanization in China. China World Econ. 2014, 22, 19-36. [CrossRef]

136. Schwab, K. The Global Competitiveness Report 2011-2012; World Economic Forum: Geneva, Switzerland, 2011.

137. Schwab, K. The Global Competitiveness Report 2013-2014; World Economic Forum: Geneva, Switzerland, 2013.

138. Schwab, K. The Global Competitiveness Report 2015-2016; World Economic Forum: Geneva, Switzerland, 2015.

139. Jick, T.D. Mixing qualitative and quantitative methods: Triangulation in action. Adm. Sci. Q. 1979, 24, 602-611. [CrossRef]

140. Trentin, A.; Forza, C.; Perin, E. Embeddedness and path dependence of organizational capabilities for mass customization and green management: A longitudinal case study in the machinery industry. Int. J. Prod. Econ. 2015, 169, 253-276. [CrossRef]

141. Alvesson, M. Beyond neo-positivism, romanticism and localism: A reflexive approach to interviews. Acad. Manag. Rev. 2003, 28, 13-33. [CrossRef]

142. Yin, R.K. Case Study Research: Design and Methods, 4th ed.; Sage Publications: London, UK, 2009.

143. Zhao, M.; Park, S.H.; Zhou, N. MNC strategy and social adaptation in emerging markets. J. Int. Bus. Stud. 2014, 45, 842-861. [CrossRef]

144. Wang, K.; Qi, X.; Liu, H.; Song, J. Deep belief network based k-means cluster approach for short-term wind power forecasting. Energy 2018, 165, 840-852. [CrossRef]

145. Thampapillai, D. Environmental Economics: Concepts, Methods and Policies; Oxford University Press: Melbourne, Australia, 2002.

146. Baughn, C.C.; Bodie, N.L.; McIntosh, J.C. Corporate social and environmental responsibility in Asian countries and other geographical regions. Corp. Soc. Responsib. Environ. Manag. 2007, 14, 189-205. [CrossRef]

147. Oman, C. Policy Competition for Foreign Direct Investment: A Study of Competition among Governments to Attract FDI; OECD: Paris, France, 2000.

148. Ramus, C.A.; Steger, U. The Roles of Supervisory Support Behaviors and Environmental Policy in Employee Ecoinitiatives at Leading-Edge European Companies. Acad. Manag. J. 2000, 43, 605-626.

149. Ciarli, T.; Valente, M. The complex interactions between economic growth and market concentration in a model of structural change. Struct. Chang. Econ. Dyn. 2016, 38, 38-54. [CrossRef]

150. Hanif, I. Impact of fossil fuels energy consumption, energy policies, and urban sprawl on carbon emissions in East Asia and the Pacific: A panel investigation. Energy Strat. Rev. 2018, 21, 16-24. [CrossRef]

151. Crane, A.; Matten, D. Business Ethics: A European Perspective; Oxford University Press: Oxford, UK, 2004.

152. Zeng, S.X.; Meng, X.H.; Yin, H.T.; Tam, C.M.; Sun, L. Impact of cleaner production on business performance. J. Clean. Prod. 2010, 18, 975-983. [CrossRef]

153. Kirca, A.H.; Bearden, W.O.; Roth, K. Implementation of market orientation in the subsidiaries of global companies: The role of institutional factors. J. Acad. Mark. Sci. 2011, 39, 683-699. [CrossRef]

154. Yu, T.; Subramaniam, M.; Cannella, A.A., Jr. Competing globally, allying locally: Alliances between global rivals and host-country factors. J. Int. Bus. Stud. 2013, 44, 117-137. [CrossRef]

155. Auh, S.; Menguc, B. Balancing exploration and exploitation: The moderating role of competitive intensity. J. Bus. Res. 2005, 58, 1652-1661. [CrossRef]

156. Yakovleva, N.; Vazquez-Brust, D.A. Mining multinational enterprises and artisanal small-scale miners: From confrontation to cooperation. J. World Bus. 2018, 53, 52-62. [CrossRef]

157. Davis, R.; Franks, D. Costs of Company-Community Conflict in the Extractive Sector; Corporate social responsibility initiative report No. 66; Harvard Kennedy School: Cambridge, MA, USA, 2014.

158. Blanchard, O. Macroeconomics, 4th ed.; Prentice Hall: Upper Saddle River, NJ, USA, 2006.

159. Frank, B.; Enkawa, T. How Economic Growth Affects Customer Satisfaction. Asia Pac. Manag. Rev. 2008, 13, 531-544.

160. Wu, J.; Ma, Z.; Liu, Z. The moderated mediating effect of international diversification, technological capability, and market orientation on emerging market firms' new product performance. J. Bus. Res. 2018. Available online: https://www.sciencedirect.com/science/article/pii/S014829631830153X (accessed on 6 February 2019). [CrossRef] 
161. Yun, J.J.; Jeong, E.; Lee, Y.K.; Kim, K.H. The effect of open innovation on technology value and technology transfer: A comparative analysis of the automotive, robotics, and aviation industries of Korea. Sustainability 2018, 10, 2459. [CrossRef]

162. Eisenhardt, K.M.; Tabrizi, B.N. Accelerating adaptive processes: Product innovation in the global computer industry. Adm. Sci. Q. 1995, 40, 84-110. [CrossRef]

163. Clark, K.B. Project scope and project performance: The effect of parts strategy and supplier involvement on product development. Manag. Sci. 1989, 35, 1247-1263. [CrossRef]

164. Wang, H.; Tong, L.; Takeuchi, R.; George, G. Corporate social responsibility: An overview and new research directions. Acad. Manag. J. 2016, 59, 534-544. [CrossRef]

165. Carpentier, C.L.; Ervin, D.E. Business Approaches to Agri-Environmental Management: Incentives, Constraints and Policy Issues; OECD: Paris, France, 2002.

166. Khanna, M. Non-mandatory approaches to environmental regulation: A survey. J. Econ. Surv. 2001, 15, 291-324. [CrossRef]

167. Henisz, W.J.; Dorobantu, S.; Nartey, L.J. Spinning gold: The financial returns to stakeholder engagement. Strat. Manag. J. 2014, 35, 1727-1748. [CrossRef]

168. Kannabiran, G. Sustainable stakeholder engagement through innovative supply chain strategy: An exploratory study of an Indian organization. Asian Bus. Manag. 2009, 8, 205-223. [CrossRef]

169. Sharma, S. Managerial interpretations and organizational context as predictors of corporate choice of environmental strategy. Acad. Manag. J. 2000, 43, 681-697.

170. Wang, M.; Zhao, X.; Gong, Q.; Ji, Z. Measurement of regional green economy sustainable development ability based on entropy weight-topsis-coupling coordination degree-A case study in Shandong Province, China. Sustainability 2019, 11, 280. [CrossRef]

171. Newman, K.L. Organizational transformation during institutional upheaval. Acad. Manag. Rev. 2000, 25, 602-619. [CrossRef]

172. Scherer, A.G.; Palazzo, G. The new political role of business in a globalized world: A review of a new perspective on CSR and its implications for the firm, governance, and democracy. J. Manag. Stud. 2011, 48, 899-931. [CrossRef]

173. Djelic, M.-L.; Sahlin-Andersson, K. Transnational Governance: Institutional Dynamics of Regulation; Cambridge University Press: Cambridge, UK, 2006.

(C) 2019 by the authors. Licensee MDPI, Basel, Switzerland. This article is an open access article distributed under the terms and conditions of the Creative Commons Attribution (CC BY) license (http://creativecommons.org/licenses/by/4.0/). 